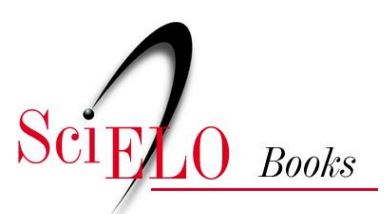

\title{
9. Chaves de identificação para adultos
}

\author{
Cleber Galvão \\ Carolina Dale
}

\section{SciELO Books / SciELO Livros / SciELO Libros}

GALVÃO, C., and DALE, C. Chaves de identificação para adultos. In: GALVÃO, C., org. Vetores da doença de chagas no Brasil [online]. Curitiba: Sociedade Brasileira de Zoologia, 2014, pp. 171-208. Zoologia: guias e manuais de identificação series. ISBN 978-85-98203-09-6. Available from SciELO Books $<$ http://books.scielo.org $>$.

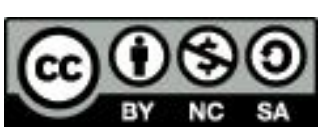

All the contents of this chapter, except where otherwise noted, is licensed under a Creative Commons Attribution-Non Commercial-ShareAlike 3.0 Unported.

Todo o conteúdo deste capítulo, exceto quando houver ressalva, é publicado sob a licença Creative Commons Atribuição Uso Não Comercial - Partilha nos Mesmos Termos 3.0 Não adaptada.

Todo el contenido de este capítulo, excepto donde se indique lo contrario, está bajo licencia de la licencia Creative Commons Reconocimento-NoComercial-CompartirIgual 3.0 Unported. 


\title{
9. Chaves de identificação para adultos
}

\section{(Cleber Galvão \& Carolina Dale)}

\author{
"- E agora estou perdido! Devo parar? \\ - Não, se páras, estás perdido." \\ (Goethe, Poemas)
}

Neste capítulo são apresentadas chaves dicotômicas pictóricas atualizadas para todas as tribos e gêneros da subfamília Triatominae. Nas chaves específicas foram incluídas todas as espécies de triatomíneos encontradas no Brasil. No caso dos gêneros Rhodnius e Panstrongylus foram incluídas todas as espécies conhecidas mesmo as que não ocorrem no Brasil. No caso dos gêneros Bolbodera, Linshcosteus, Dipetalogaster, Hermanlentia, Meccus, Mepraia, Nesotriatoma e Paratriatoma as chaves específicas não foram incluídas porque não possuem representantes no Brasil.

\section{Chave para as tribos e gêneros da subfamília Triatominae}

1. Ocelos não elevados, situados ao nível do tegumento, pouco visíveis entre os grânulos da cabeça, ou situados sobre ou próximo do sulco interocular

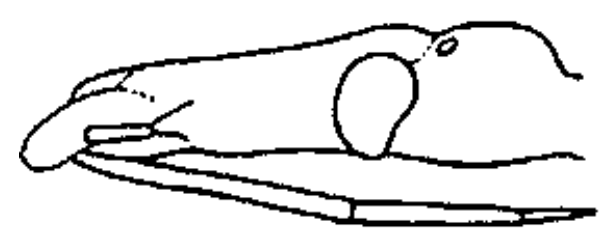

Ocelos situados em nítidas saliências do disco na região pós-ocular da cabeça

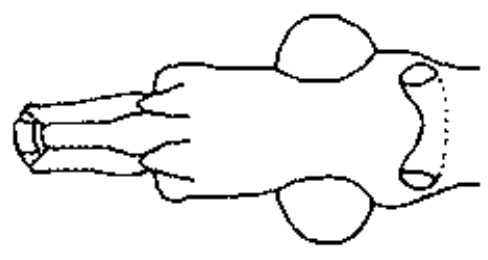

2. Cabeça na maioria dos casos alongada, sub-cônica, não fortemente convexa dorsalmente na vista lateral; genas grandes, alongadas, projetadas para diante do nível do ápice do clípeo; tubérculos anteníferos implantados adiante do meio da região ante-ocular da cabeça e com projeção lateral apical espinhosa; ocelos situados diretamente sobre o disco da região pós-ocular da cabeça; sulco interocular pouco visível; cório com nervuras nítidas; tegumento do corpo fortemente 
rugoso e granuloso [tribo Bolboderini] .3
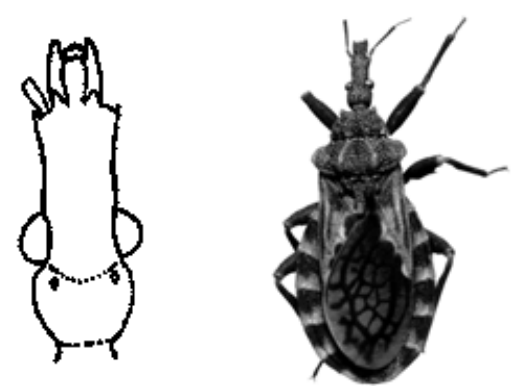

Cabeça ovoide, fortemente convexa dorsalmente na vista lateral; genas menos nítidas, não ultrapassando o nível do ápice do clípeo; tubérculos anteníferos implantados junto ao bordo anterior dos olhos e sem processo apical lateral setífero; ocelos situados sobre o sulco interocular ou imediatamente atrás dele; sulco interocular fortemente curvado para trás e quase atingindo o nível do bordo posterior da cabeça; cório com nervuras pouco visíveis; tegumento do corpo liso, mas com pelos longos, numerosos e suberectos [tribo Cavernicolini]. Cavernicola

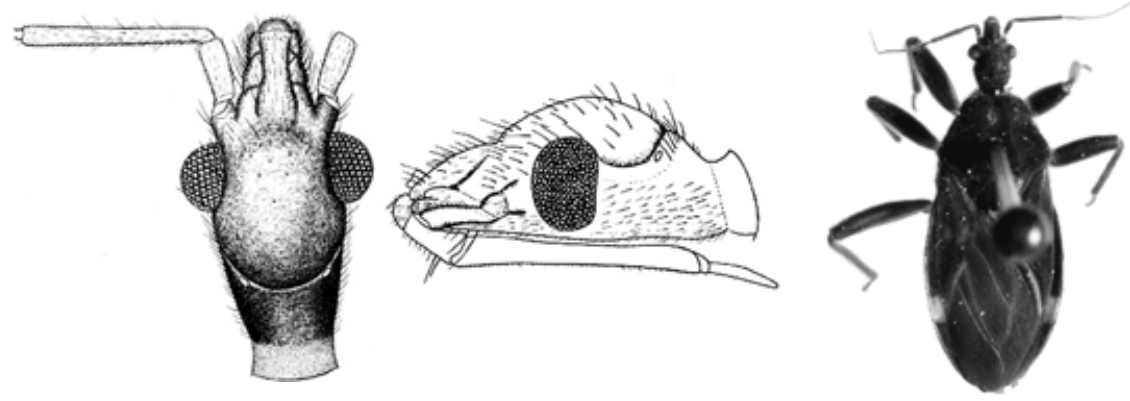

3. Rostro com o primeiro artículo maior ou tão longo quanto o segundo; escutelo, na base, com 1 + 1 processos sub-laterais triangulares; conexivo dorsal com nítida crista longitudinal sub-lateral. Belminus
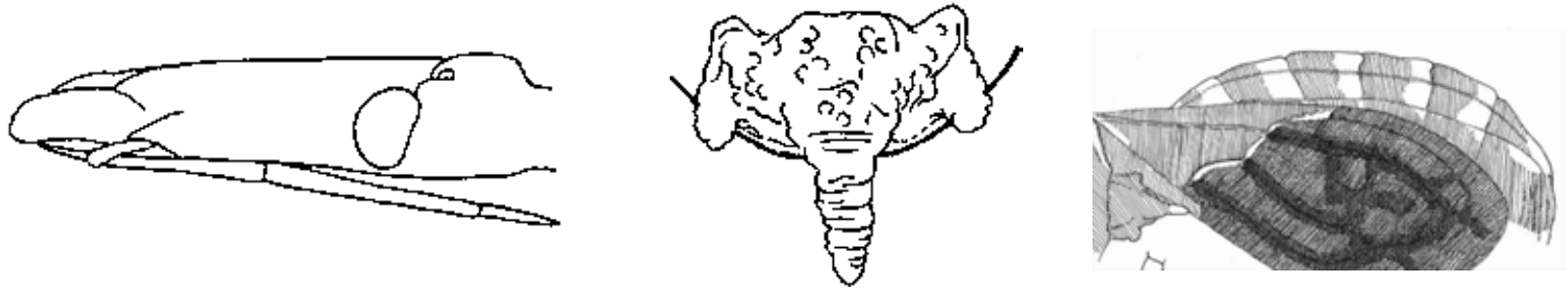

Rostro com o primeiro artículo muito mais curto que o segundo; escutelo sem processos sub-laterais na base; conexivo dorsal plano. .4
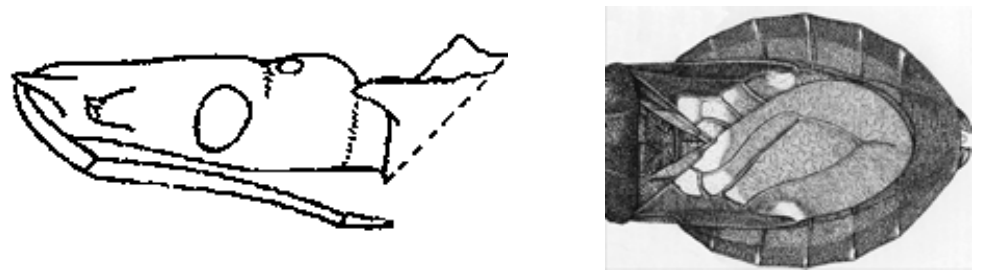
4. Escutelo trapezoidal, de bordo posterior reto, sem processo posterior; primeiro urotergito descoberto Parabelminus

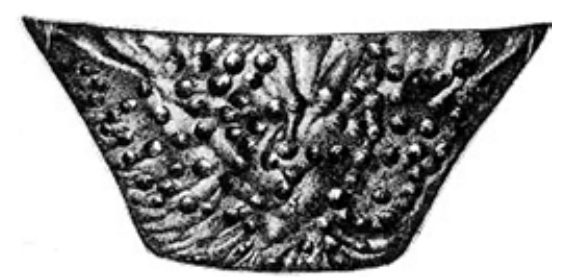

Escutelo triangular, com processo apical posterior desenvolvido; primeiro urotergito não exposto.

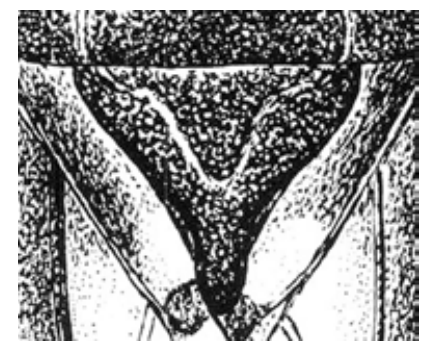

5. Genas achatadas lateralmente; fêmures sem espinhos; tíbias com fosseta esponjosa em todas as pernas; tarsos com dois segmentos curtos, juntos medem cerca de um quinto do comprimento das tíbias. Microtriatoma
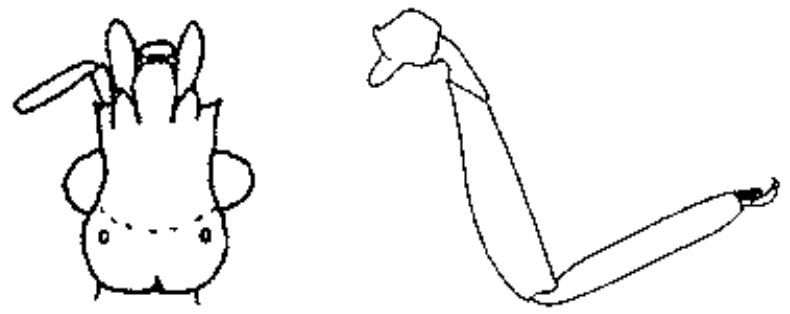

Genas espiniformes; fêmures com espinhos; fosseta esponjosa tibial ausente; tarsos com três segmentos, com cerca de um terço do comprimento das tíbias. Bolbodera

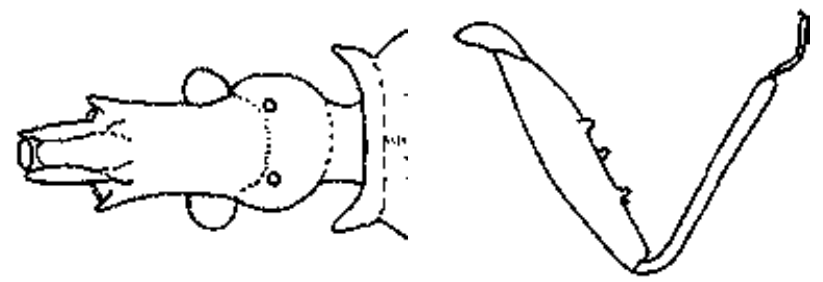

6. Cabeça com nítida calosidade lateral pós-ocular provida de tubérculos setíferos; antenas implantadas em tubérculos inseridos perto do ápice da cabeça ... [tribo Rhodniini]. 7
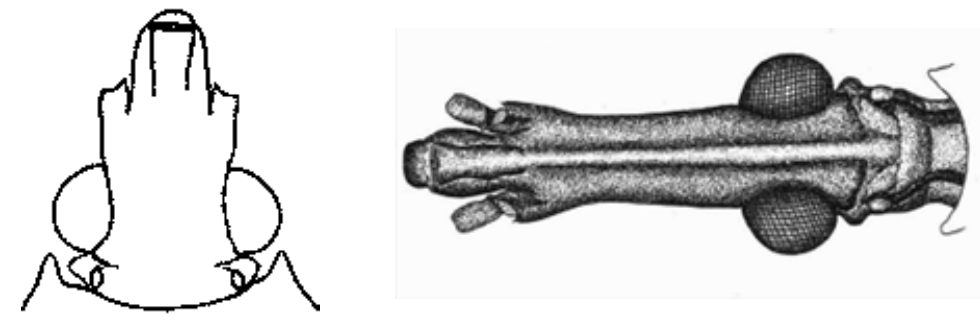
Cabeça sem calosidade lateral pós-ocular provida de tubérculos setíferos; antenas implantadas em tubérculos afastados do ápice da cabeça

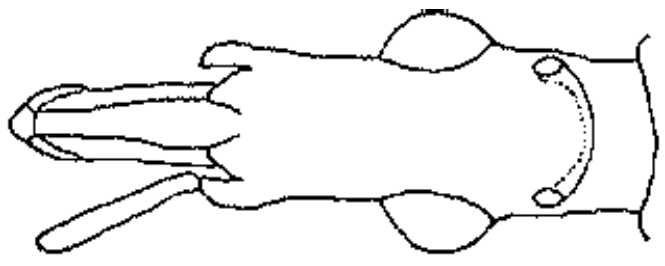

7. Cabeça subtriangular, algo achatada, de comprimento nitidamente menor que o dobro da sua largura incluindo os olhos; região pós-ocular muito curta, seu comprimento com um quarto a um terço da largura; artículo apical do rostro profundamente emarginado distalmente; fêmures nitidamente dilatados e achatados lateralmente. Psammolestes
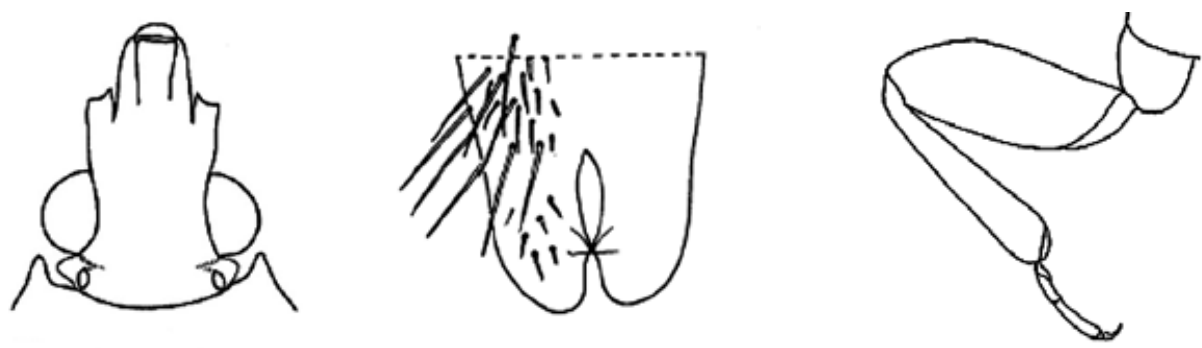

Cabeça subcilíndrica, não achatada dorso-ventralmente, de comprimento com o dobro ou mais do dobro da sua largura incluindo os olhos; região pós-ocular mais longa, pelo menos com a metade da largura; terceiro artículo do rostro pontudo no ápice; fêmures alongados na maioria das espécies, subcilíndricos, nunca achatados lateralmente. Rhodnius

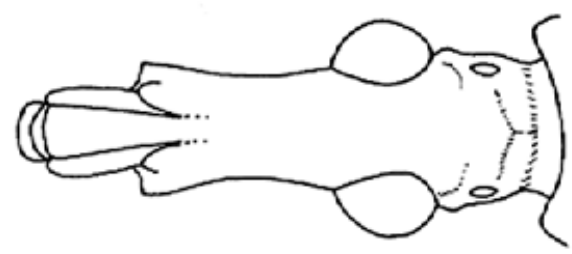

8. Comprimento total do inseto não atingindo $9 \mathrm{~mm}$; cabeça muito curta e larga, não mais longa que a largura de lado a lado dos olhos; clípeo mais dilatado antes do meio; hemélitros com pequeno ramo conectando a porção basal da $\mathrm{R}+\mathrm{M}$ a Sc

[tribo Alberproseniini] Alberprosenia
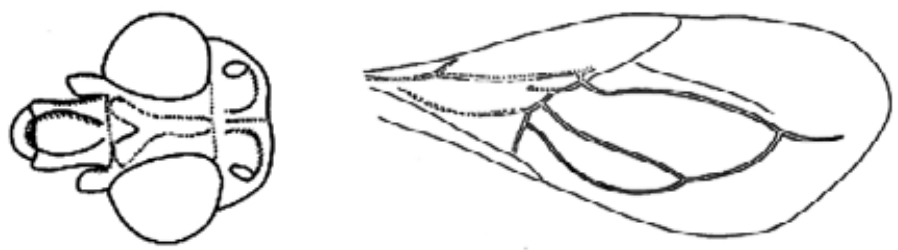
Inseto com comprimento total maior que $9 \mathrm{~mm}$; cabeça mais alongada, mais que a largura de lado a lado dos olhos; sem pequeno ramo conectando a porção basal da R+M a Sc ......[tribo

Triatomini] .9
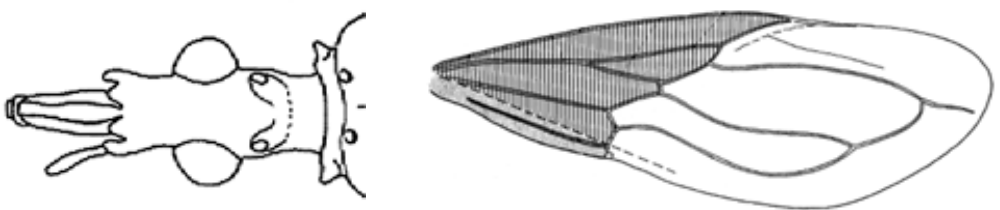

9. Cabeça muito curta e larga; tubérculos anteníferos inseridos muito perto, junto, do bordo anterior dos olhos (Fig. 9A); cabeça e corpo glabros ou com pelos achatados curtos

Panstrongylus

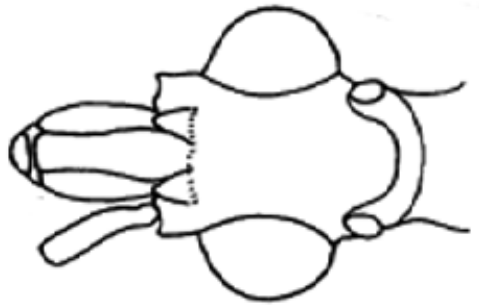

Cabeça de forma variada, na maior parte dos casos subcilíndrica; tubérculos anteníferos não inseridos na proximidade dos olhos; em raros casos, cabeça comparativamente curta e tubérculos anteníferos relativamente próximos dos olhos, mas então cabeça e corpo com pelos longos semi-eretos 10

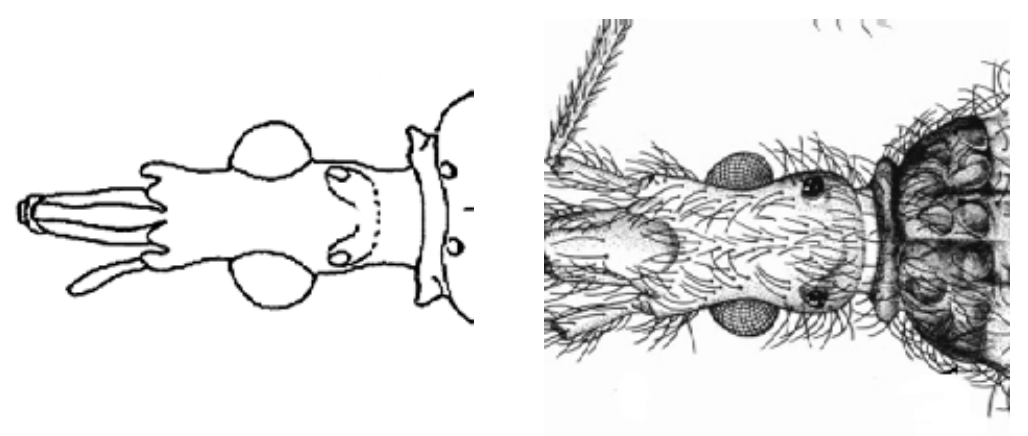

10. Rostro não ultrapassando, para trás, o nível dos olhos; prosterno sem sulco estridulatório. Gênero de ocorrência restrita à Índia. Linshcosteus
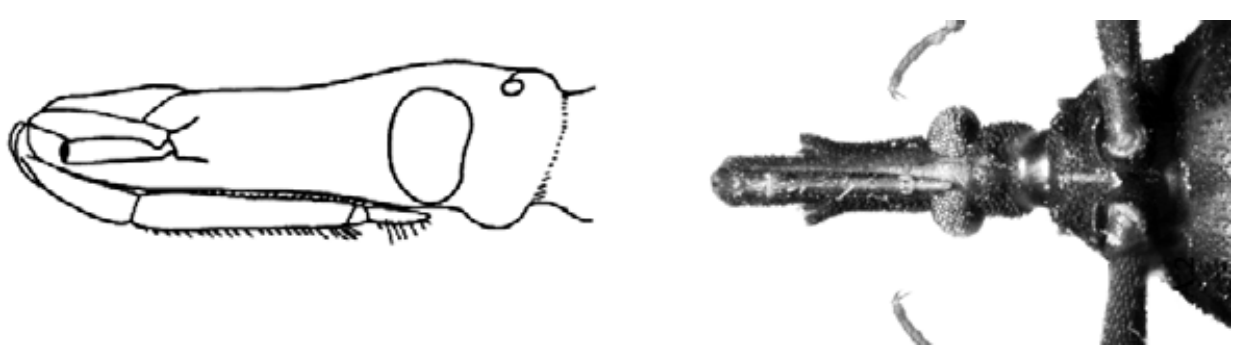
Rostro atingindo o prosterno; sulco estridulatório prosternal presente

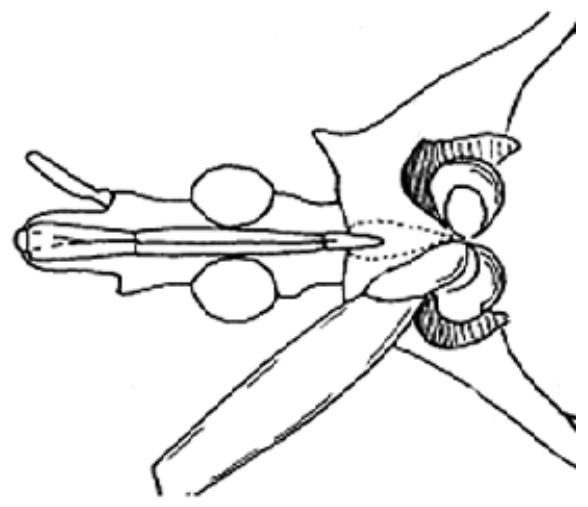

11. Escutelo com processo apical tão ou mais comprido que o corpo principal do escutelo, oblíquo, com a forma de forte espinho aguçado; rostro com o primeiro artículo muito longo, quase tão longo quanto o segundo, terminando ao nível do meio da distância entre o tubérculo antenífero e o bordo anterior do olho Eratyrus

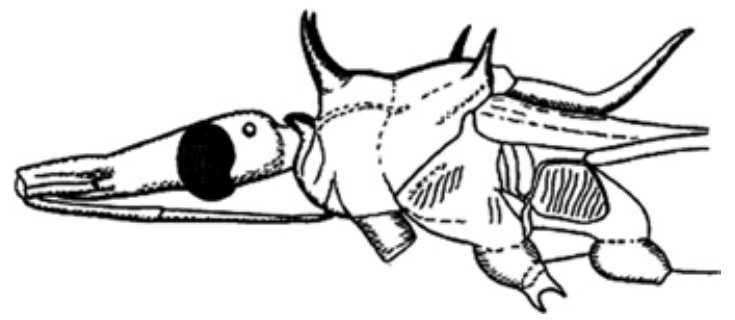

Escutelo com processo apical com aspecto diferente; rostro com o primeiro artículo nitidamente mais curto que o segundo, não ultrapassando o nível da inserção do tubérculo antenífero 12

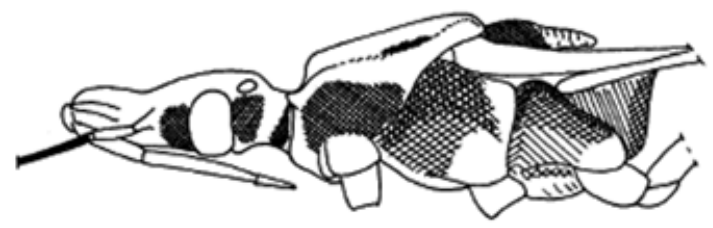

12. Cabeça, corpo e apêndices com abundantes pelos compridos, curvos, semi-eretos; cabeça fortemente convexa dorsalmente; olhos pequenos; tubérculos anteníferos inseridos perto do bordo anterior dos olhos; fêmures anteriores sem dentículos; fossetas esponjosas ausentes; comprimento total do inseto de 12,5 a 14,5 mm. Gênero monotípico de ocorrência restrita aos Estados Unidos e México Paratriatoma (P. hirsuta)

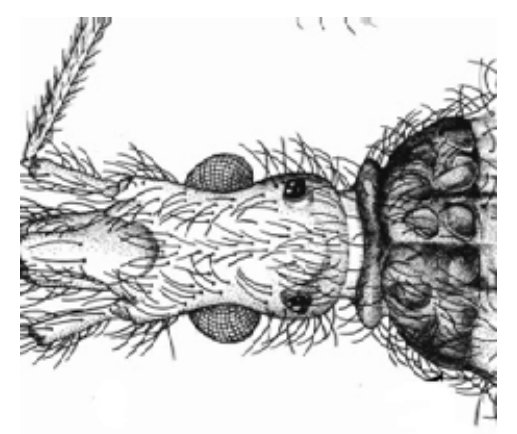


Cabeça, corpo e apêndices parecendo lisos ou com pelos curtos, ou somente os apêndices com pelos compridos, porém menos numerosos que acima; cabeça menos convexa dorsalmente; olhos maiores; tubérculos anteníferos inseridos no meio ou perto do meio da região ante-ocular da cabeça, afastados dos olhos; fêmures anteriores na maioria das espécies com dois ou mais dentículos; fossetas esponjosas presentes ou ausentes; comprimento 9,5 a $42 \mathrm{~mm}$

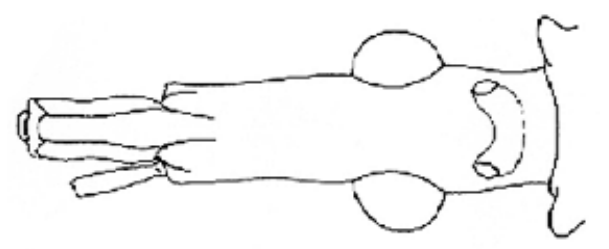

13. Abdômen das fêmeas com membrana unindo as placas dorsal e ventral do conexivo; fêmures sem espinhos; atípico polimorfismo (machos ápteros, macrópteros ou braquípteros e fêmeas micrópteras); espécie de tamanho mediano com 18 a 22 mm de comprimento. Gênero de ocorrência restrita ao Chile. Mepraia

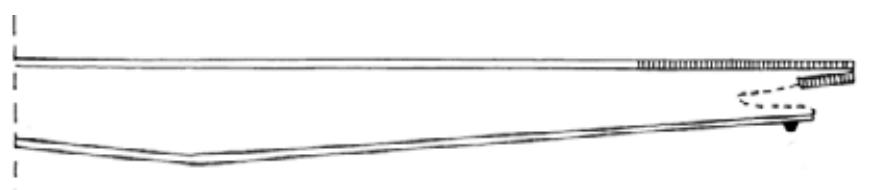

Placas ventral e dorsal do conexivo unidas diretamente, sem membranas; fêmures espinhosos ou não; machos e fêmeas sempre alados, macrópteros ou raramente braquípteros; espécies raramente com mais de $30 \mathrm{~mm}$ de comprimento. 14

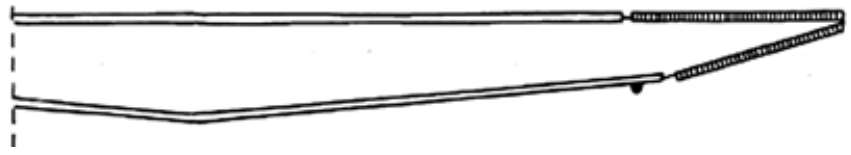

14. Membrana dos hemélitros muito clara, de cor creme quase branca, não contrastando com as veias; veia M livre, não fusionada com a R. Gênero monotípico de ocorrência restrita ao Peru. Hermanlentia (H. matsunoi)

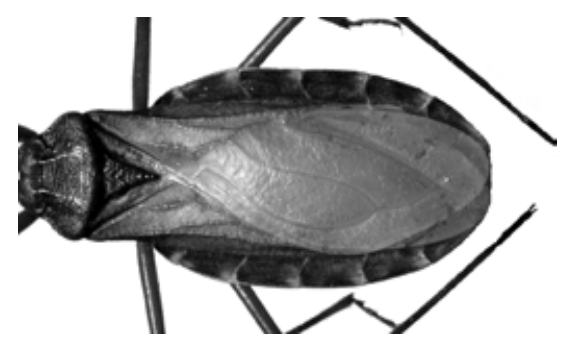

Membrana dos hemélitros mais escura, veias contrastando com as células, veia M fundida com a R.......15 15. Largura do abdômen com cerca de um terço do comprimento total do corpo; pronoto com tubérculos bem aparentes; hemélitro mais curto e estreito que o abdômen, deixando o conexivo e os últimos segmentos abdominais expostos; insetos grandes, de 27 a $40 \mathrm{~mm}$ de comprimento. 
Gênero com seis espécies Mexicanas. Meccus

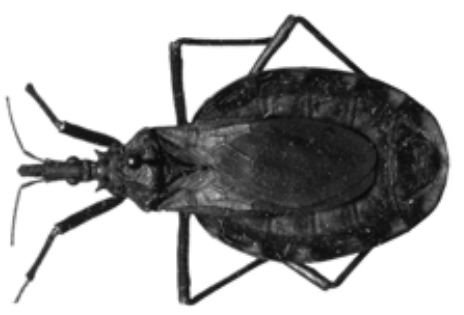

Largura do abdômen com menos de um terço do comprimento total do corpo; pronoto com ou sem tubérculos evidentes; hemélitro não tão estreito ou curto, na maioria das espécies cobrindo parte do conexivo e o último segmento abdominal

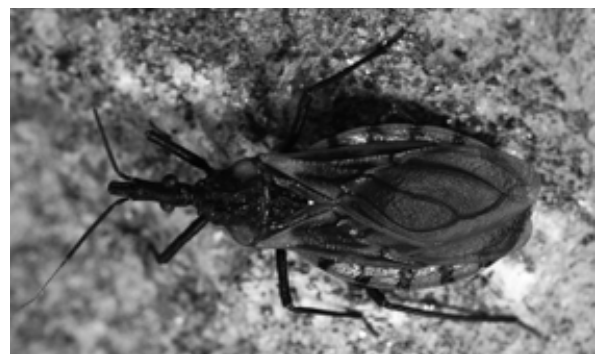

16. Ângulos humerais do pronoto sub-angulares, dilatados; margem anterior do escutelo com dois processos espiniformes projetando-se em direção ao lobo posterior do pronoto. Gênero com três espécies de ocorrência restrita ao Caribe. Nesotriatoma

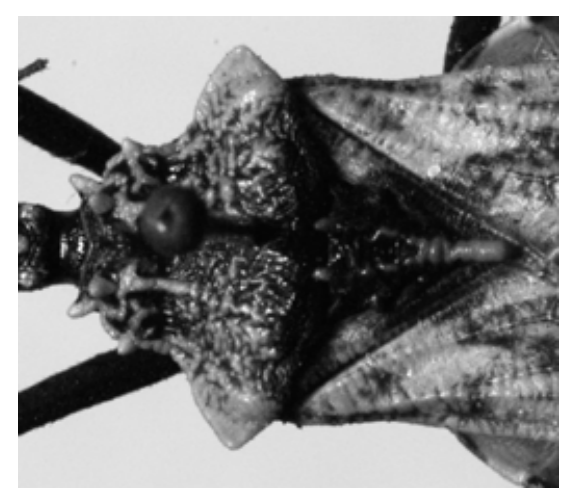

Ângulos humerais do pronoto não angulares margem anterior do escutelo sem os processos espiniformes descritos acima.

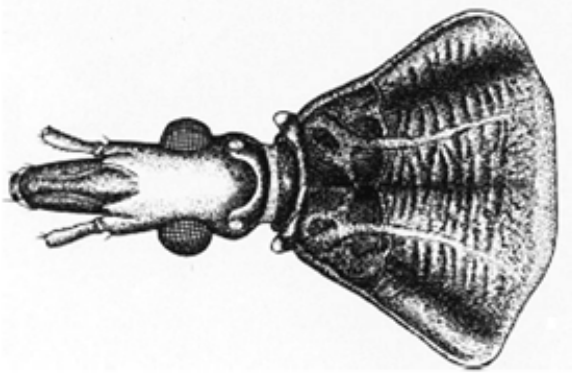


17. Indivíduos muito grandes, de 33 a $44 \mathrm{~mm}$ de comprimento; placas ventrais do conexivo imperceptíveis; nítida membrana conectando os urotergitos e as placas ventral e dorsal do conexivo; processo mediano do pigóforo curto, retangular transversalmente e truncado no ápice. Gênero monotípico de ocorrência restrita ao sul da Baixa Califórnia (México). Dipetalogaster (D. maxima)
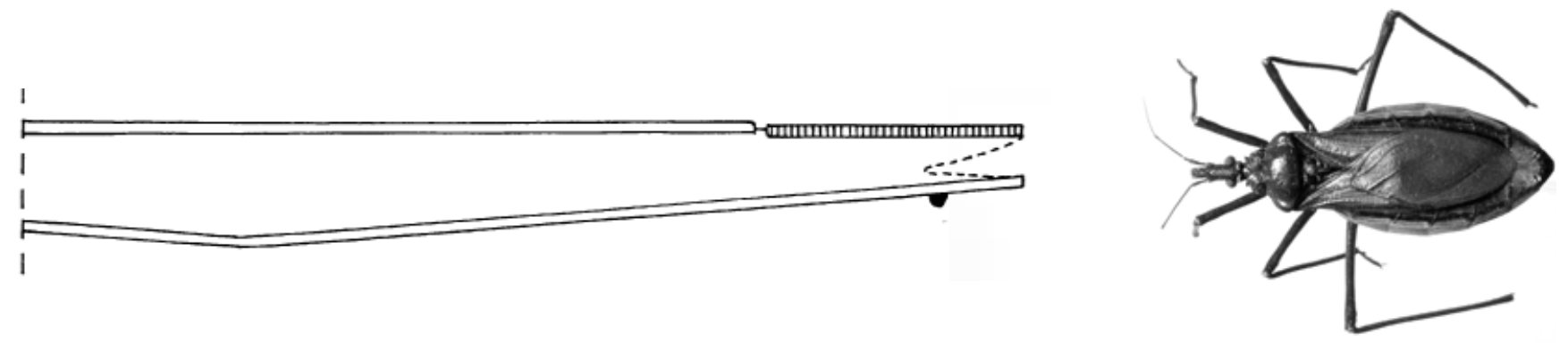

Indivíduos com menos de $30 \mathrm{~mm}$, raramente com $33 \mathrm{~mm}$ ou mais; placas ventrais do conexivo distintas, embora em alguns casos muito estreitas; processo do pigóforo cônico e estreitando no ápice; gênero com o maior número de espécies e amplamente distribuído. Triatoma

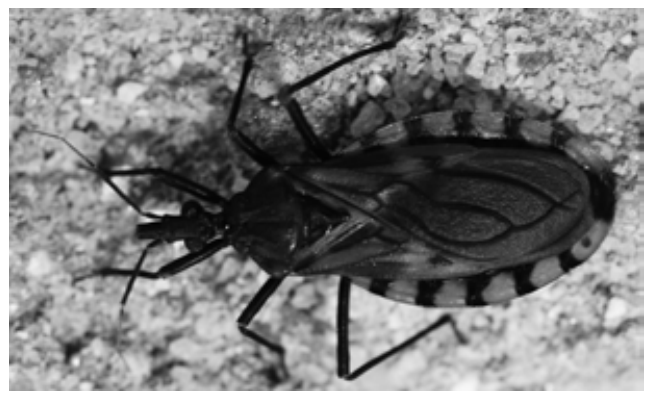

\section{Chave para as espécies do gênero Cavernicola}

Tegumento escuro, quase negro com manchas amarelas no IV segmento do conexivo; região anteocular da cabeça mais curta que a pós-ocular; ocelos situados após a sutura pós-ocular; processo apical do escutelo mais longo que o corpo do escutelo e paralelo ao corpo. Cavernicola lenti

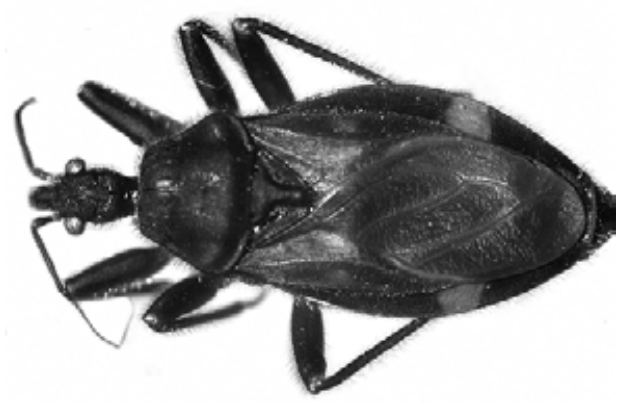


Tegumento mais claro; região anteocular da cabeça do mesmo tamanho ou ligeiramente mais longa que a pós-ocular; ocelos situados sobre ou tocando o bordo da sutura pós-ocular; processo apical do escutelo pequeno, voltado para cima, quase vertical. Cavernicola pilosa

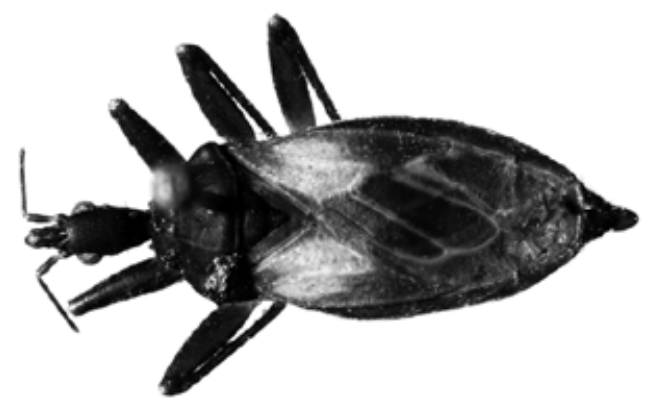

Chave para as espécies do gênero Eratyrus (segundo Lent \& Wygodzinsky, 1979)

1. Lobo anterior do pronoto com $1+1$ espinhos discais fortes; ângulos humerais do pronoto nitidamente espinhosos; cório com mancha subapical avermelhada comparativamente pequena, anteriormente não atingindo o nível da nervura transversa m-cu. Eratyrus mucronatus

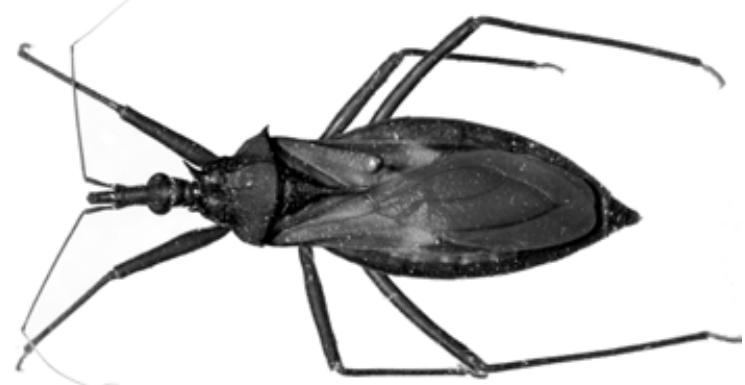

Lobo anterior do pronoto com 1 + 1 tubérculos discais pouco elevados e arredondados no ápice; ângulos humerais do pronoto apenas aguçados ou pontudos, mas não espinhosos; mancha subapical avermelhada do cório relativamente grande, atingindo ou ultrapassando anteriormente o nível da nervura transversa m-cu. Eratyrus cuspidatus

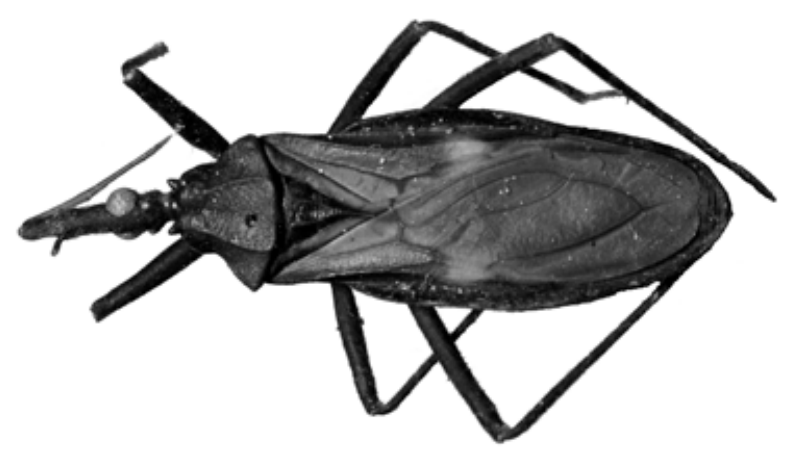




\section{Chave para as espécies do gênero Microtriatoma (segundo Lent \& Wygodzinsky, 1979)}

1. Membrana dos hemélitros manchada de claro e escuro; cabeça delgada de perfil, região pós-ocular no máximo uma vez e meia $(1,6: 1)$ mais larga que longa; terceiro artículo do rostro muito mais curto que o primeiro $(0,7-0,8: 1)$. Microtriatoma trinidadensis

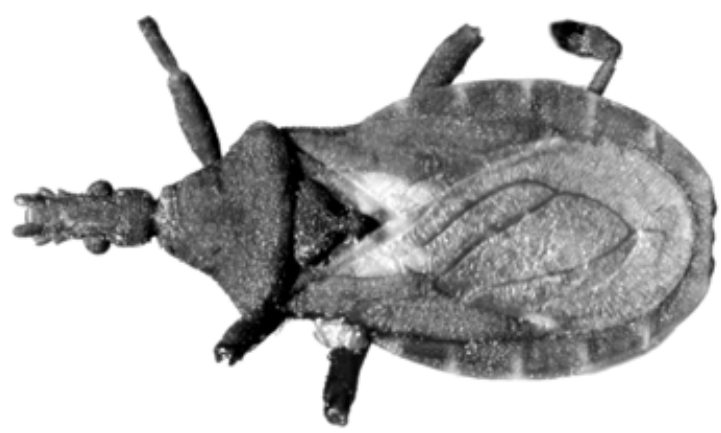

Membrana dos hemélitros de coloração escura uniforme; cabeça robusta de perfil, região pós- ocular mais que uma vez e meia $(1,8: 1)$ tão larga quanto longa; terceiro artículo do rostro tão longo quanto o primeiro Microtriatoma borbai

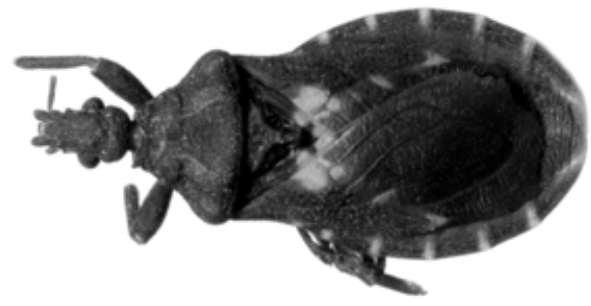

\section{Chave para as espécies do gênero Psammolestes (segundo Lent \& Wygodzinsky, 1979)}

1. Tegumento da cabeça e do tórax muito polido e brilhante; cabeça sem constrição antes do pescoço, quando observada de perfil; cabeça dorsalmente com larga faixa amarelada ocupando inteiramente a região interocular; rostro com terceiro artículo e ápice do segundo provido de pelos longos; ângulos antero-laterais do pronoto muito salientes e projetados até o nível dos ocelos; genitália do macho com suporte do falosoma grande, constituído de duas estruturas fusionadas. Psammolestes arthuri

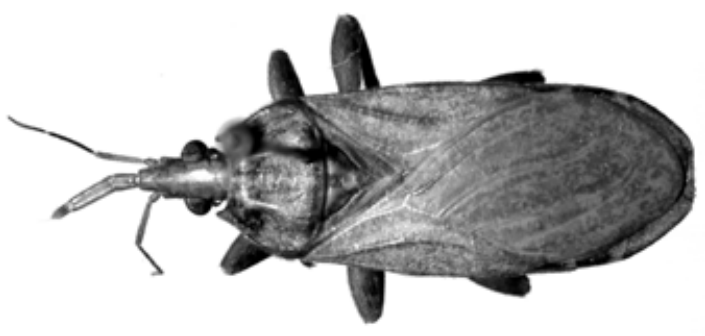

Tegumento da cabeça e tórax fosco; cabeça, constrita antes do pescoço, quando observada lateralmente; cabeça dorsalmente castanho-amarelada clara e pintada de escuro ou escura e com estreita linha longitudinal dorsal amarela; rostro com terceiro e segundo artículos inteiramente 
revestidos de pelos longos; ângulos ântero-laterais do pronoto mais curtos, não atingindo adiante o nível dos ocelos; genitália do macho com suporte do falosoma menor, composto de duas estruturas separadas.

2

2. Cabeça tão longa ou levemente mais curta que a largura ao nível dos olhos; região anteocular não mais do que o dobro do comprimento da pós-ocular; cabeça em declive acentuado atrás dos ocelos; ângulos ântero-laterais do pronoto acuminados; genitália do macho com suporte do falosoma muito pequeno e em forma de ganchos, a esclerosamento dorsal do falosoma em forma semi-elítica Psammolestes coreodes

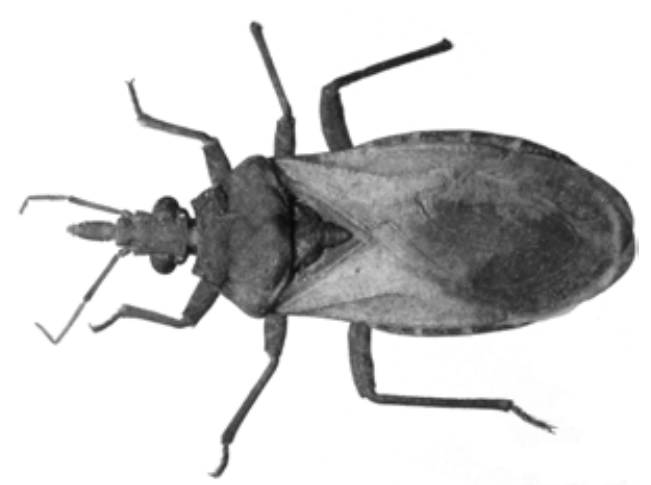

Cabeça de comprimento levemente maior que a largura ao nível dos olhos; região anteocular com duas a duas e meia vezes o comprimento da pós-ocular; cabeça em declive moderado atrás dos ocelos; ângulos ântero-laterais do pronoto muito curtos, rombos; genitália do macho com suporte do falosoma em forma de dois SS alargados e esclerosamento dorsal do falosoma arredondada apicalmente Psammolestes tertius

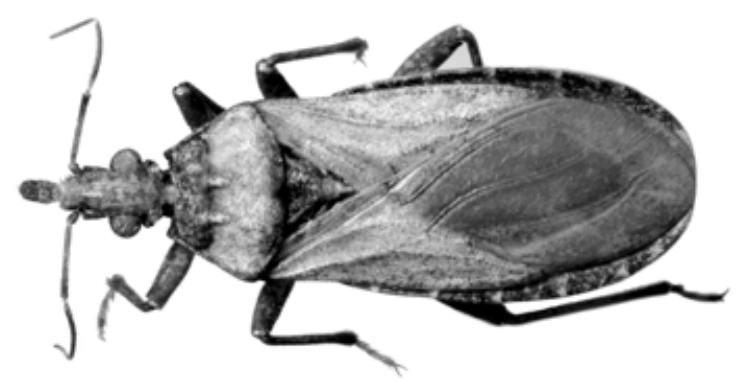

Chave para as espécies do gênero Rhodnius (R. amazonicus, R. barretti, R. dallesandroi, R. milesi, R. montenegrensis e R. zeledoni não foram incluídas na chave devido à ausência de caracteres externos diagnósticos)

1 Colorido geral da cabeça e das pernas constituído de pequenas manchas e pontos irregulares que produzem aspecto sarapintado

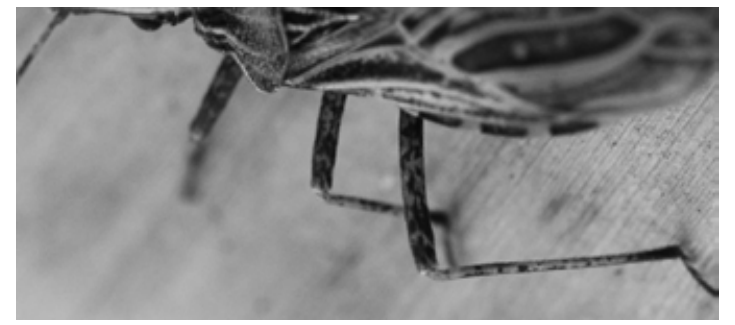


Colorido da cabeça e pernas mais uniforme, sem as pequenas manchas irregulares causadoras do aspecto sarapintado

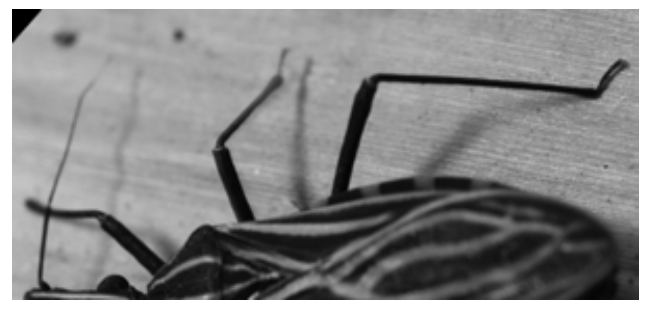

2 Tíbias de todos os pares de pernas com anel submediano escuro; conexivo dorsal com manchas retangulares escuras com forte projeção posterior em ponta, pelo menos nos segmentos 3 a 5; processo mediano do pigóforo bífido .3
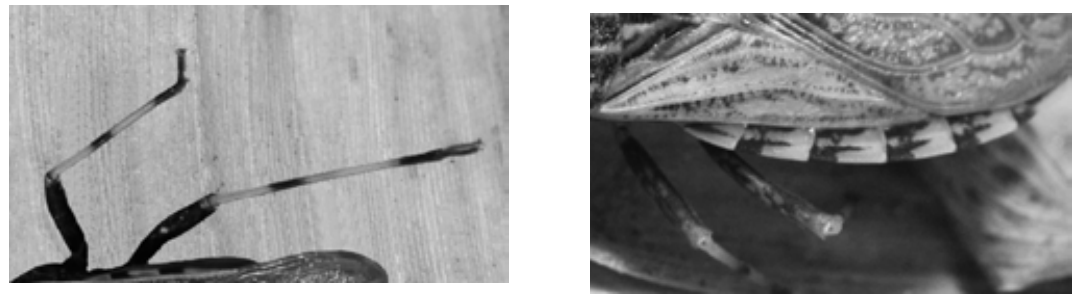

Tíbias sem o anel escuro acima indicado; conexivo dorsal com manchas retangulares escuras sem a projeção posterior em ponta, processo mediano do pigóforo não bifurcado

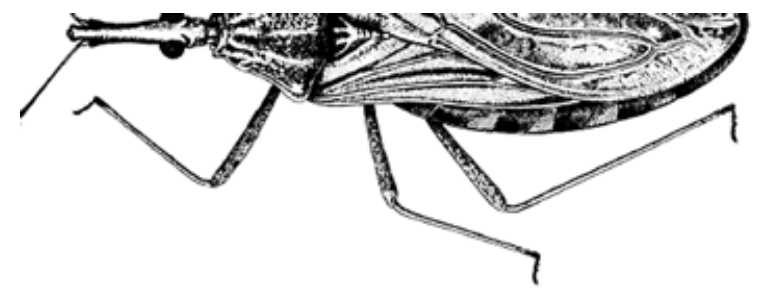

3 Região anteocular 3 vezes maior que a pós-ocular Rhodnius pictipes

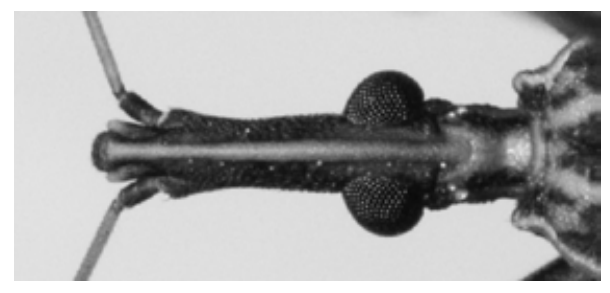

Região anteocular até 2,5 vezes maior que pós-ocular Rhodnius stali

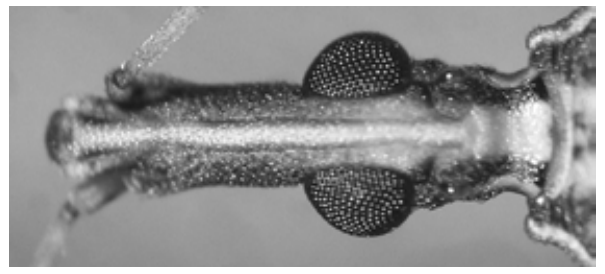


4 Espécie de tamanho grande, cerca de $22 \mathrm{~mm}$ de comprimento; cabeça alongada e maior que o pronoto; região anteocular com mais de 3 vezes o comprimento da pós-ocular; manchas retangulares do conexivo dorsal bem constituídas Rhodnius pallescens

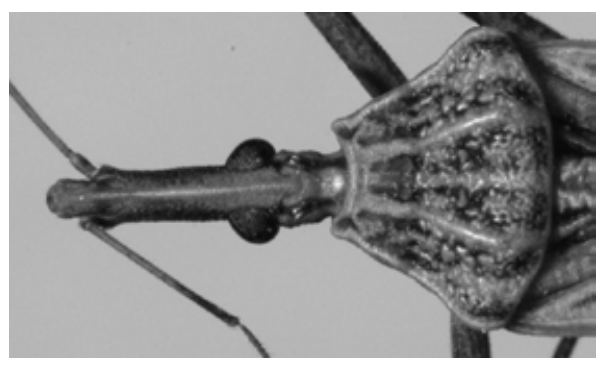

Espécie de tamanho pequeno, cerca de $14 \mathrm{~mm}$ de comprimento ou menos; cabeça de tamanho igual ou menor que o pronoto; região anteocular com menos de 3 vezes o comprimento da pós-ocular em vista dorsal; manchas escuras do conexivo dorsal difusas Rhodnius ecuadoriensis

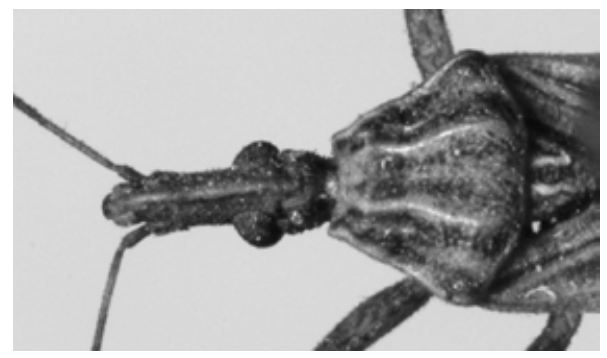

5 Espécie muito pequena entre 10,5 a $12 \mathrm{~mm}$ de comprimento; pernas nitidamente com anéis e manchas nos fêmures e tíbias; fêmures anteriores grossos com menos de 4 vezes de comprimento em relação à largura; processo do pigóforo bífido. Rhodnius paraensis
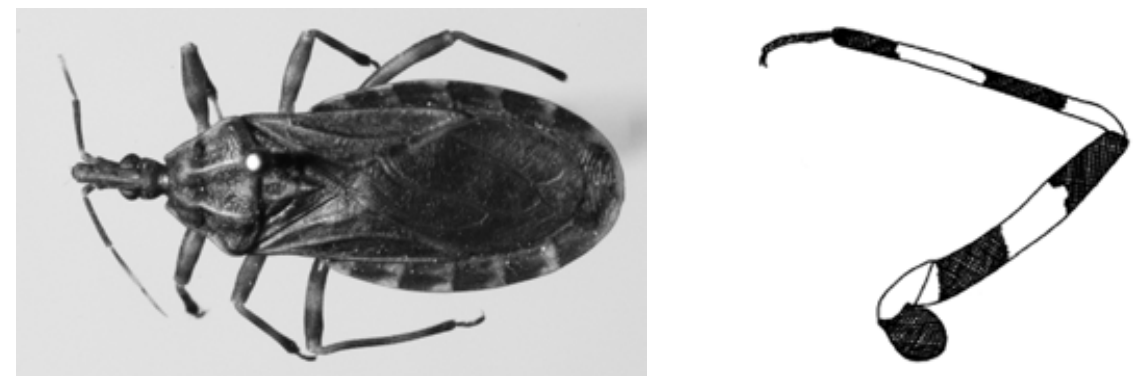

Espécies com mais de $13 \mathrm{~mm}$ de comprimento; pernas sem manchas; fêmures anteriores delgados, quatro vezes mais longos que largos; processo mediano do pigóforo não bífido 6

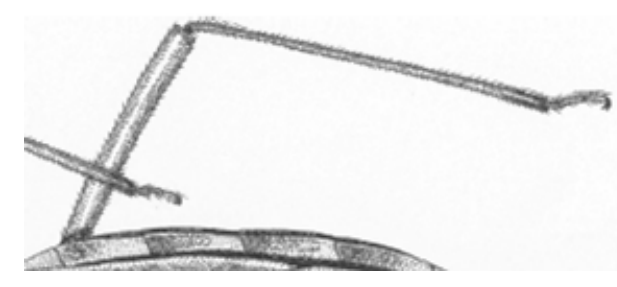


6 Pronoto muito escuro ou preto, inclusive as carenas; conexivo com pequenas manchas avermeIhadas. Rhodnius neivai

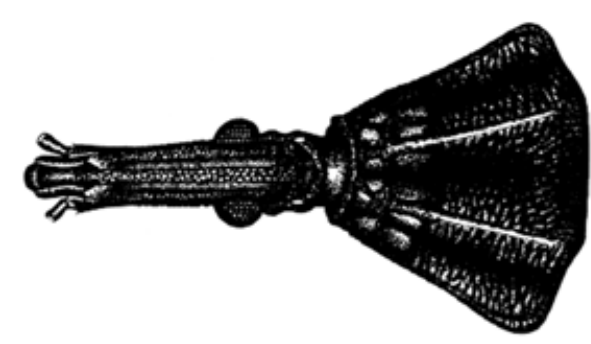

Pronoto castanho ou amarelado com partes mais escuras; conexivo claro com manchas retangulares escuras .7

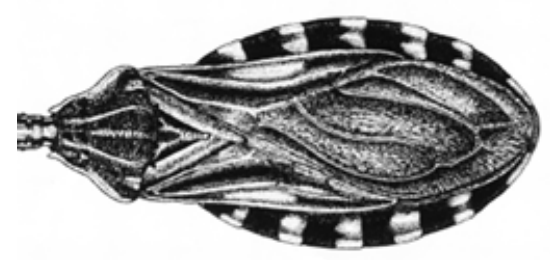

7 Cabeça proporcionalmente curta, tão comprida ou levemente maior que o pronoto (relação = 1:0,95-1,0); processo mediano do pigóforo retangular Rhodnius domesticus

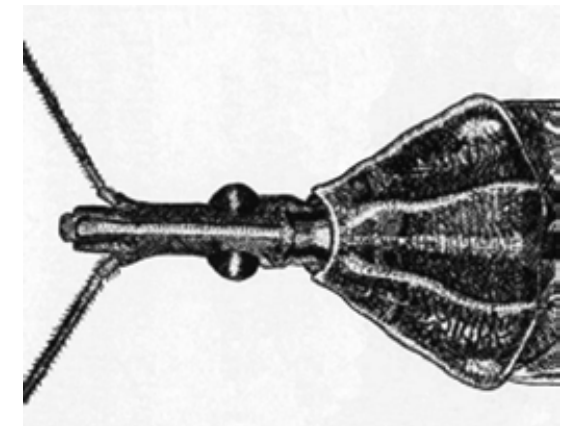

Cabeça proporcionalmente longa, de comprimento sensivelmente maior que o pronoto (relação = 1:0,65-0,80); processo mediano do pigóforo alongado, de ponta afilada ou romba. 8

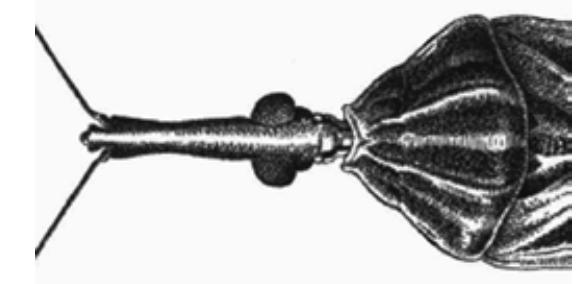

8. Lobo posterior do pronoto uniformemente preto entre as carenas submedianas, que são claras, e entre estas e os bordos laterais, também claros; antenas com terceiro artículo maior que o 
segundo; olhos distintamente mais largos na vista dorsal que à distância interocular Rhodnius brethesi

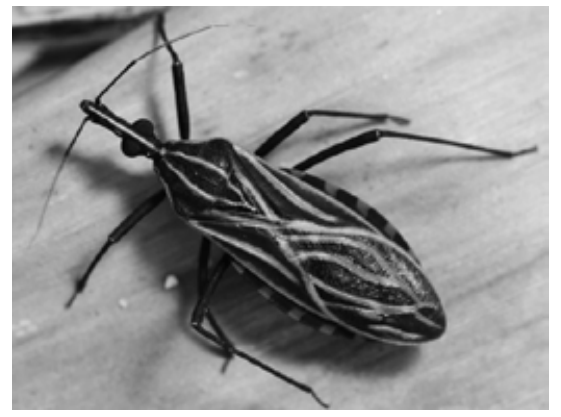

Lobo posterior do pronoto com a área entre as carenas submedianas ocupada por duas faixas escuras separadas por linha clara longitudinal do tegumento; antenas com terceiro artículo menor que o segundo; distância interocular dorsal menor ou igual à largura de um olho . .9

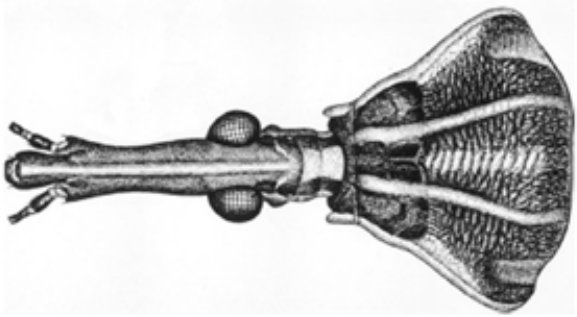

9. Ângulos ântero-laterais do pronoto salientes, dirigidos para diante; faixas escuras do lobo posterior do pronoto confluentes, principalmente as situadas entre as carenas submedianas e os bordos laterais 10

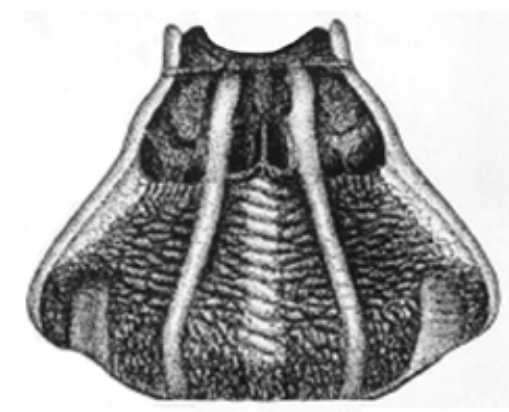

Ângulos ântero-laterais do pronoto arredondado; faixas escuras do lobo posterior do pronoto distintamente separadas

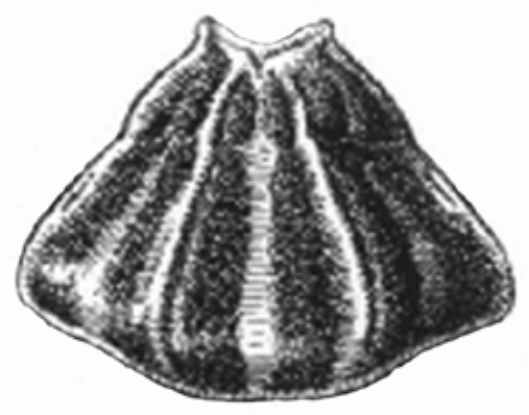


10. Inseto com 17,5 a 20,5 mm de comprimento; colorido geral castanho-escuro; trocânteres claros, contrastando fortemente com os fêmures escuros; conexivo dorsal e ventral com manchas escuras muito bem delimitadas em cada segmento; abdômen, na maioria dos espécimes, com mancha longitudinal mediana amarelada que se prolonga ao metaesterno; antena com terceiro artículo com a parte basal escura e a apical clara; processo mediano do pigóforo estreito na ba se. Rhodnius neglectus

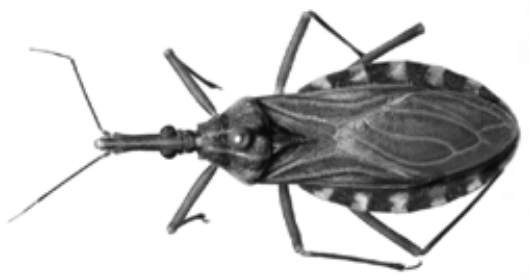

Inseto com 12,5 a 17,0 mm de comprimento; colorido geral castanho-avermelhado; trocânteres não contrastando nitidamente com o colorido dos fêmures; conexivo dorsal com manchas escuras apenas esboçadas, especialmente na superfície ventral; abdômen na face ventral sem a área clara mencionada; processo mediano do pigóforo largo na base.

Rhodnius nasutus

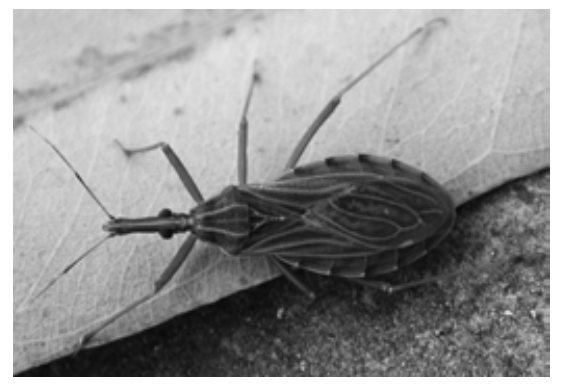

11. Comprimento dos machos $17,20 \mathrm{~mm}$ e das fêmeas $19,5-21,5 \mathrm{~mm}$; região anteocular com um pouco mais de 3 vezes o comprimento da pós-ocular; distância interocular dorsal maior que a largura dorsal de um olho, na maioria dos espécimes Rhodnius prolixus

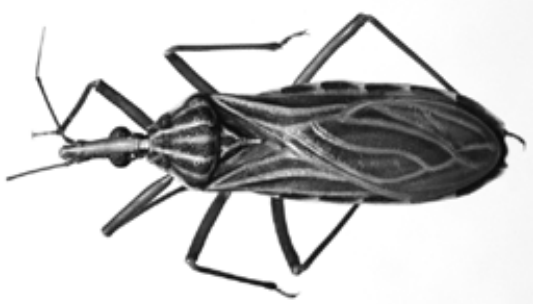

Comprimento dos machos de 20 a 23,5 mm e das fêmeas de 23 a 26 mm; região anteocular 4 vezes mais longa que a pós-ocular; distância interocular dorsal menor ou igual à largura de um olho ..Rhodnius robustus
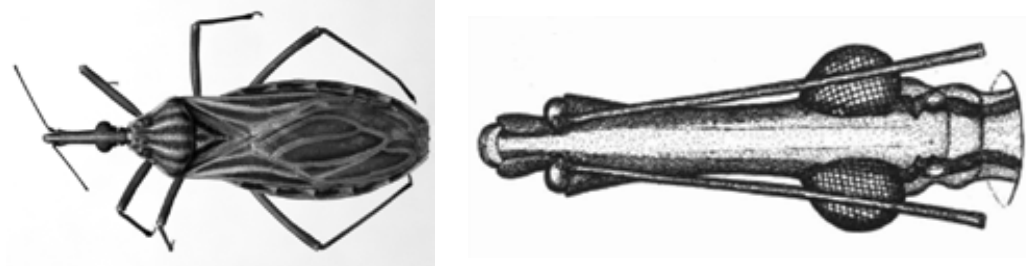


\section{Chave para as espécies do gênero Panstrongylus}

1. Processo do escutelo subcilíndrico, alongado, afilando na ponta.....................................................2

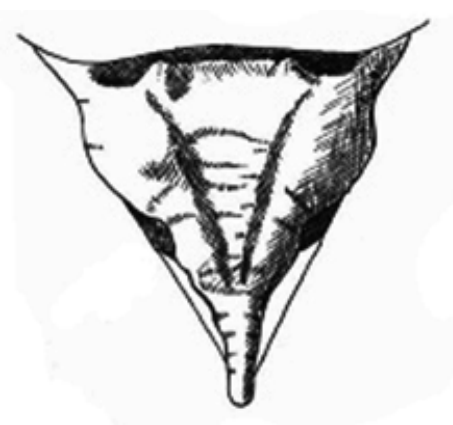

Processo do escutelo curto, arredondado, cônico ou parecendo decepado no ápice.

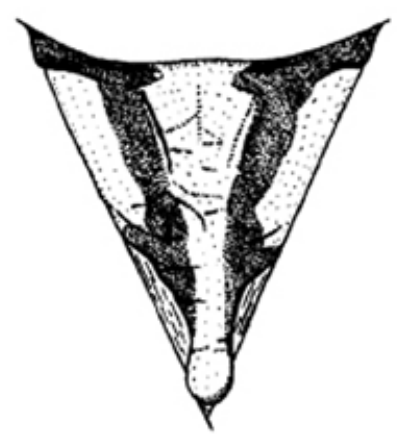

2. Espécimes quase totalmente pretos; pequena mancha vermelha no ângulo póstero-laterais dos segmentos do conexivo e, em alguns casos, marcas vermelhas no pronoto P. chinai
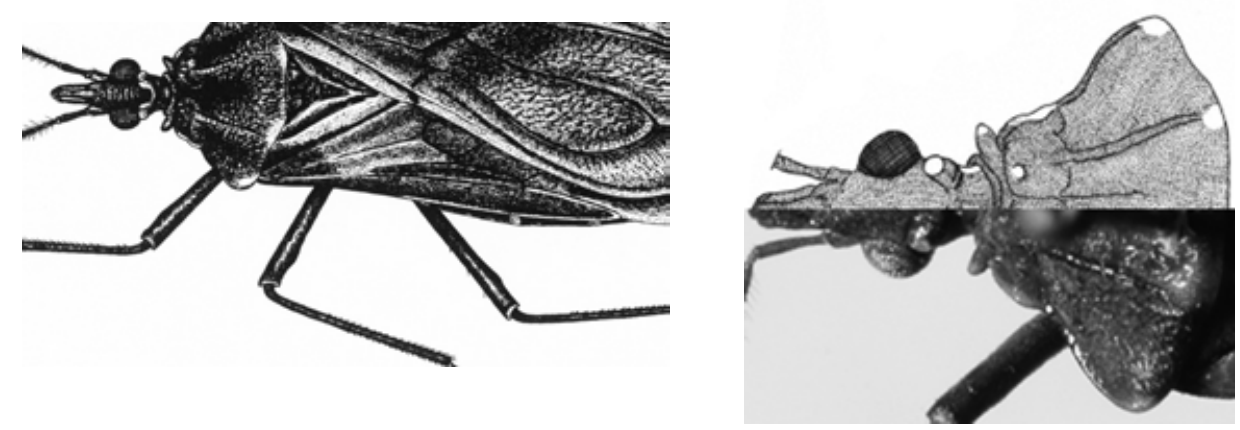

Espécimes de coloração diferente.
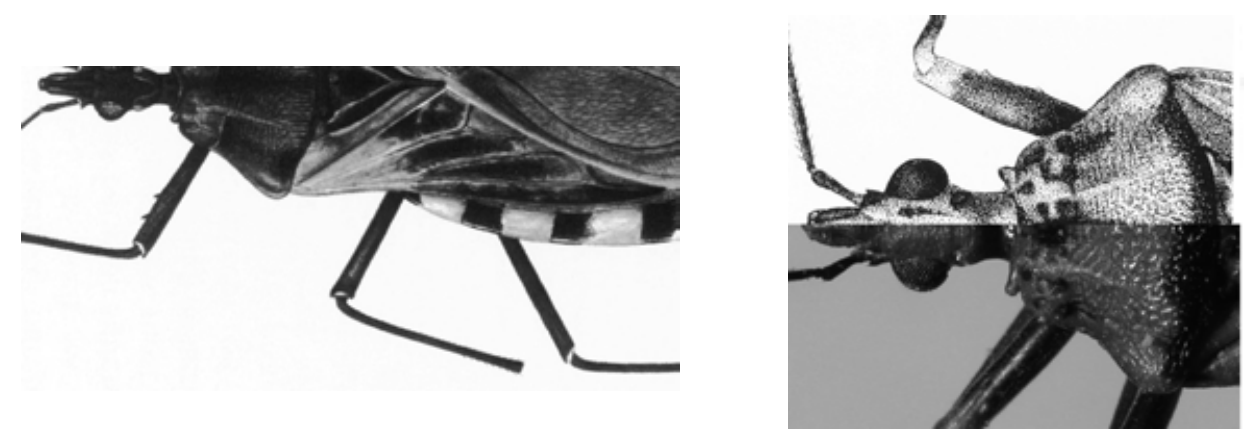


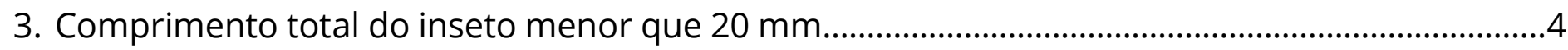
Comprimento total do inseto maior que $20 \mathrm{~mm}$; lobo anterior do pronoto com manchas pretas. .5

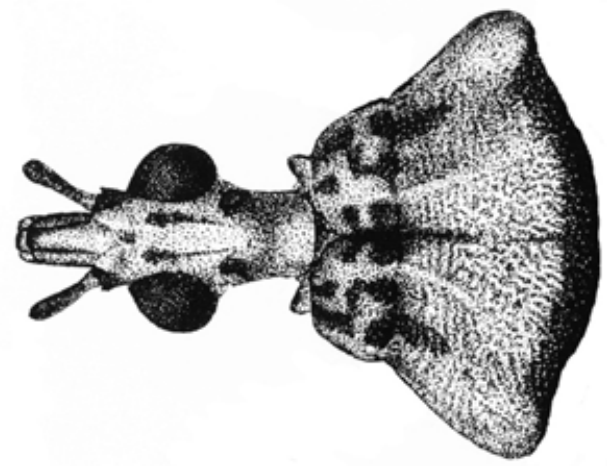

4. Lobo anterior do pronoto castanho claro sem manchas

P. lenti

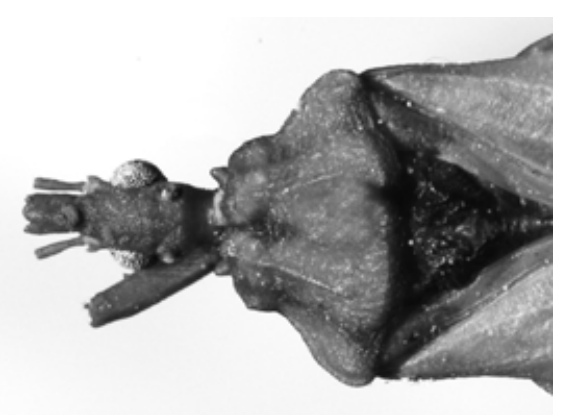

Lobo anterior do pronoto castanho amarelado com manchas. P. martinezorum

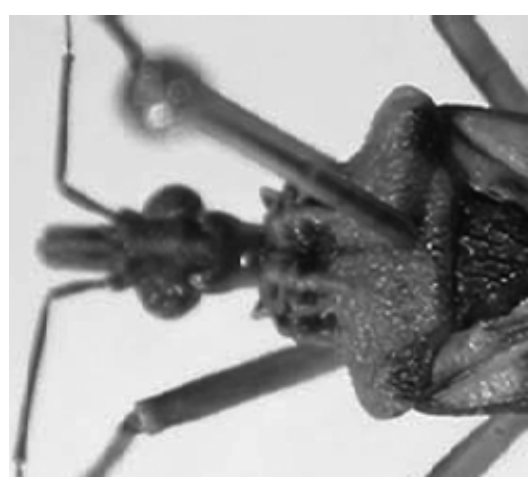

5. Abdômen ventralmente de cor clara, com séries longitudinais de manchas pretas. 6

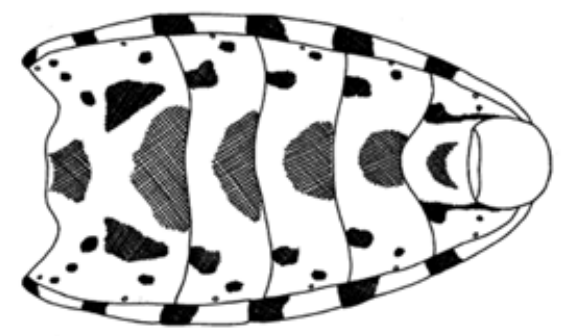


Abdômen de colorido diferente, sem séries de manchas pretas. .7

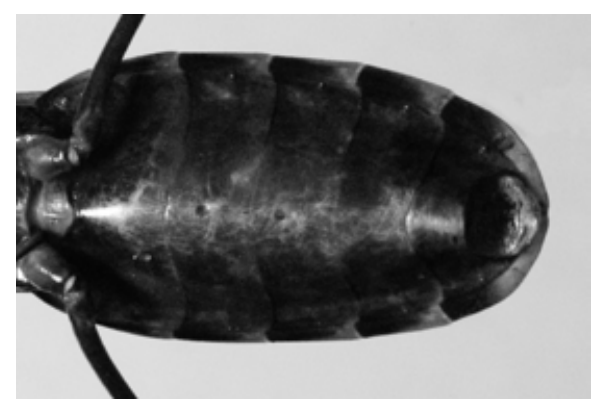

6. Pronoto com os ângulos humerais mais aguçados e apontados para fora; fêmures castanho claro com um anel mediano preto. P. mitarakaensis
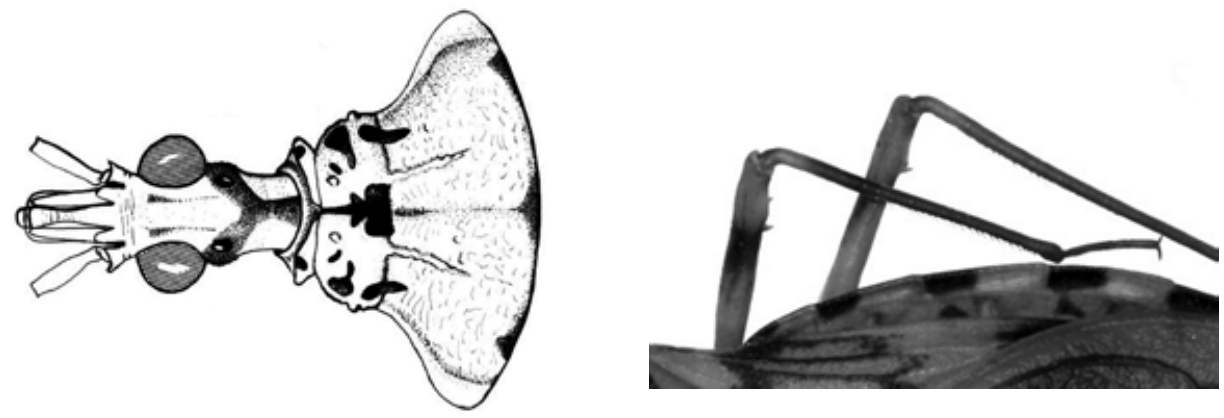

Pronoto com os ângulos humerais arredondados; fêmures pretos com o ápice avermelhado. P. geniculatus
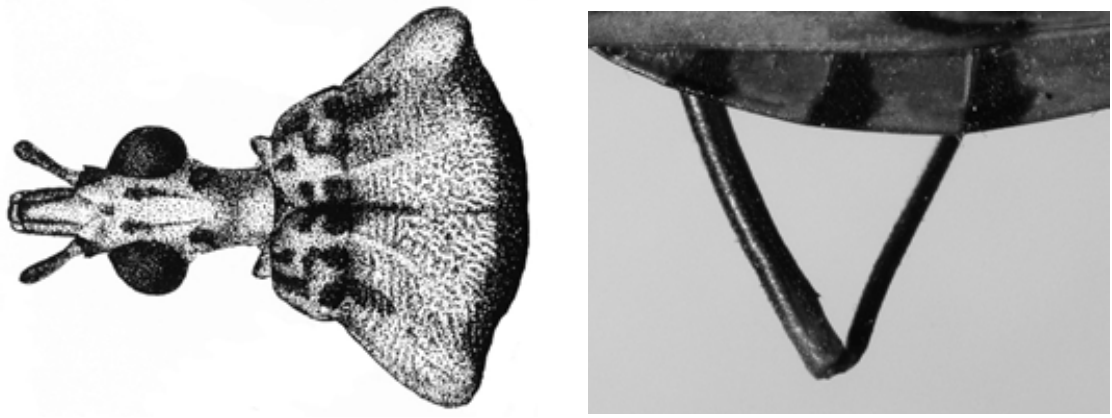

7. Rostro com o segundo artículo tão longo ou mais curto que o primeiro P. tupynambai

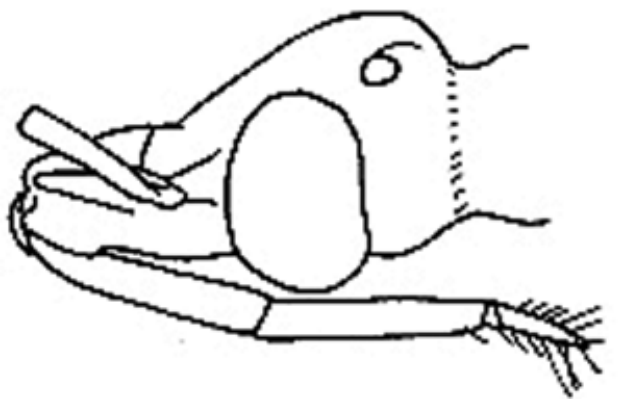


Rostro com o segundo artículo invariavelmente maior que o primeiro. 8

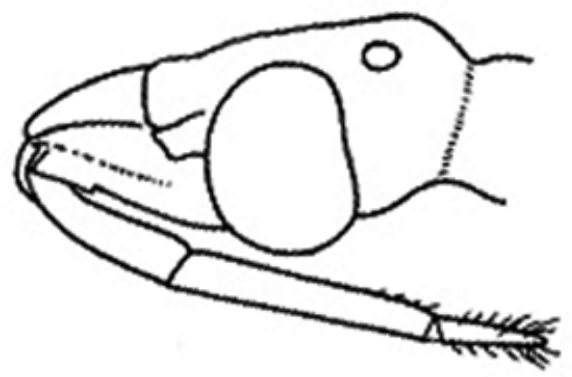

8. Cório amarelo, exceto no extremo da base e subapicalmente, contrastando com a membrana de cor cinza escura; distância interocular muito menor que o dobro da largura do olho visto dorsalmente; fêmures com leves protuberâncias subapicais. P. howardi
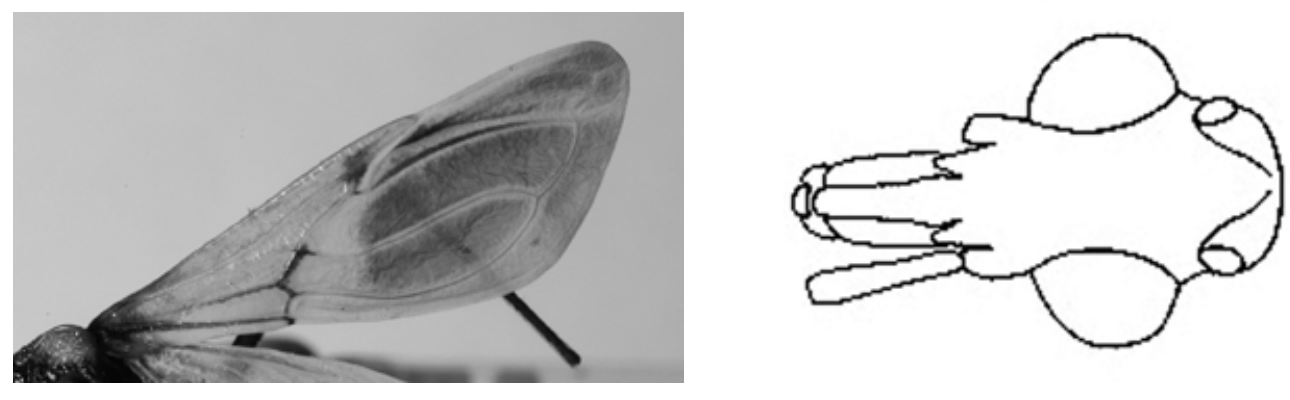

Cório tão escuro quanto a membrana, com a base e o ápice de colorido mais claro; distância interocular com o dobro ou mais que o dobro da largura do olho visto dorsalmente; fêmures anteriores e medianos com vários dentículos facilmente visíveis.
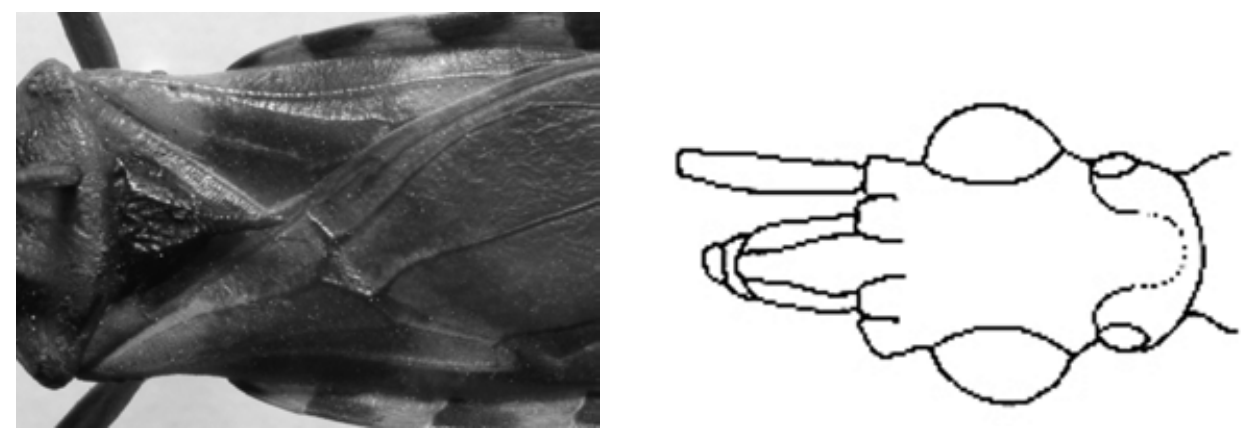

9. Lobo anterior do pronoto com tubérculos discais bem desenvolvidos.

P. lutzi

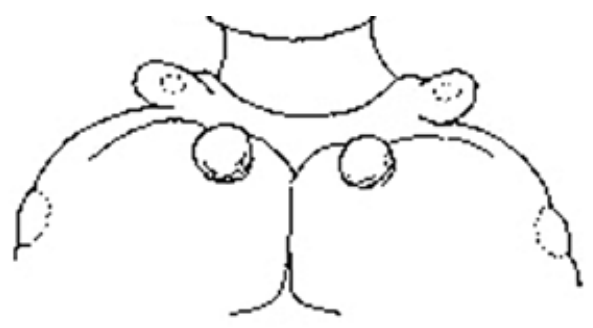


Lobo anterior do pronoto somente com tubérculos discais obsoletos ou sem eles. 10

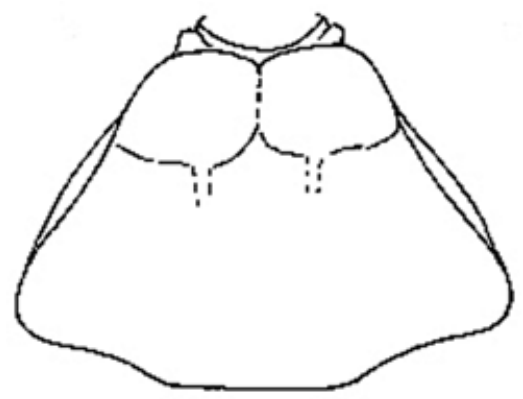

10. Ângulos ântero-laterais do pronoto muito curtos, obtusos; face superior da cabeça reta; fêmures anteriores e medianos com 2 ou 3 dentículos; bordos laterais dos lobos do pronoto formando uma linha contínua. P. diasi
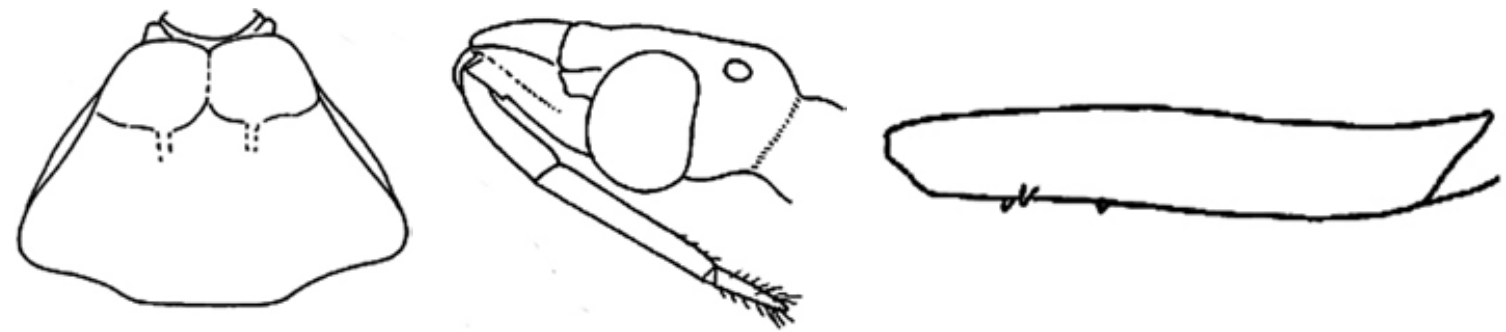

Ângulos ântero-laterais do pronoto alongados e salientes; face superior da cabeça convexa; fêmures anteriores e médios com mais de 3 dentículos cada; bordos laterais dos lobos anterior e posterior do pronto formando um ângulo nítido.

P. guentheri
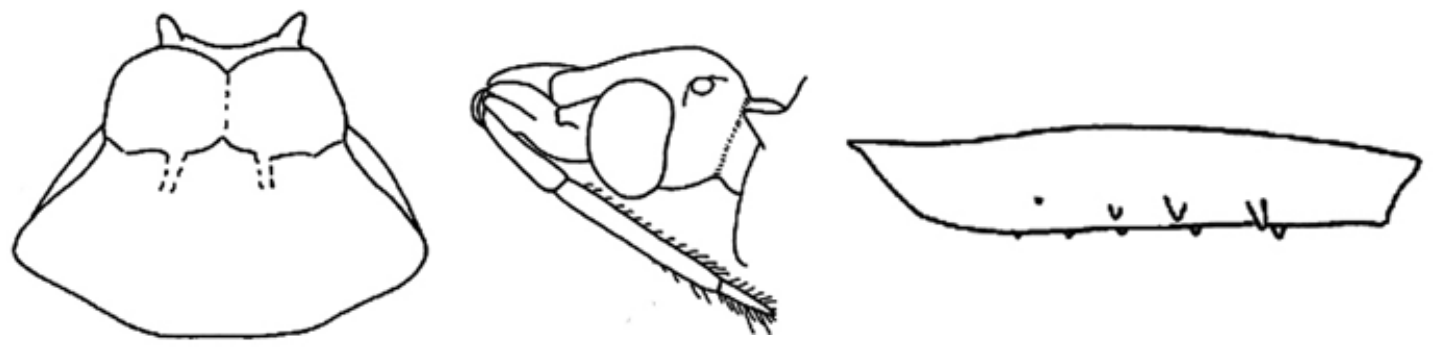

11. Jugas obtusas; tubérculos do lobo anterior do pronoto avermelhados; segmentos do conexivo com uma mancha escura no centro; tegumento do corpo em vista dorsal com cerdas douradas deitadas; hemélitros com colorido geral verde pálido P. rufotuberculatus
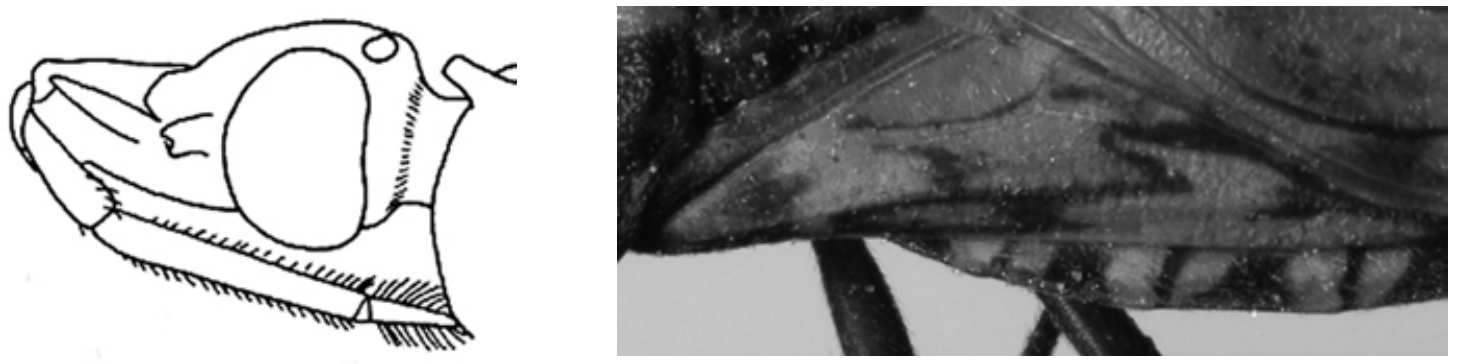
Jugas curvadas, assemelhando-se a forma de um gancho; tubérculos do lobo anterior do pronoto não ou raramente avermelhados; segmentos do conexivo com uma mancha anterior escura; tegumento do corpo em vista dorsal praticamente sem pelos; hemélitros não esverdeados.
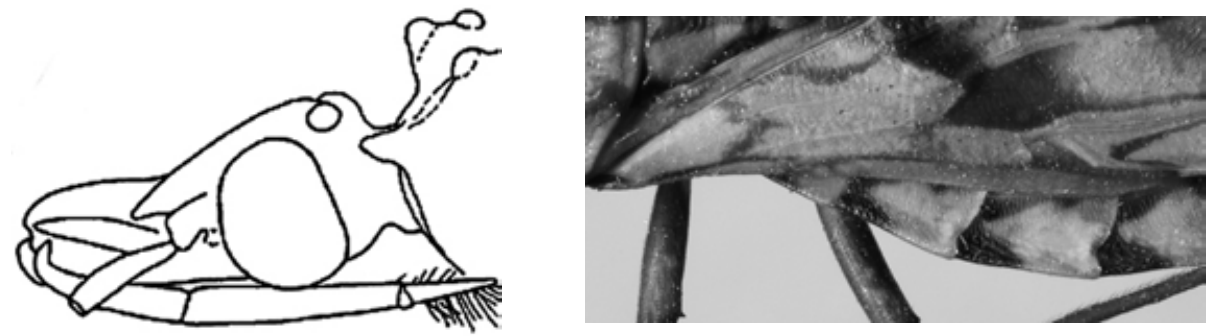

12. Inseto preto com manchas avermelhadas, $2+2$ localizadas no lobo posterior do pronoto; terceiro artículo antenal menor que o segundo. P. megistus

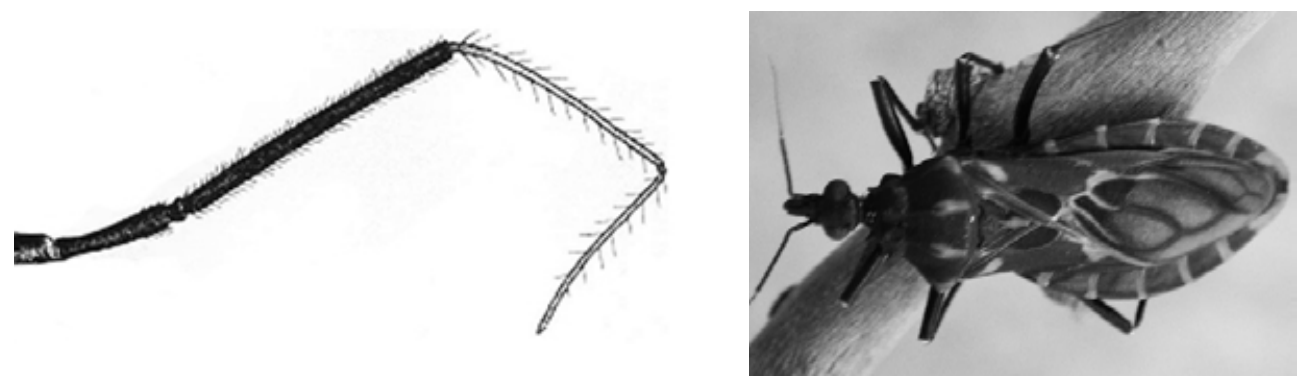

Insetos de colorido amarelado ou castanho-amarelado com manchas mais escuras; lobo posterior do pronoto de cor clara com uma faixa preta mediana e 2+2 manchas sub-laterais, longitudinais e estreitas; terceiro artículo antenal maior que o segundo. 13

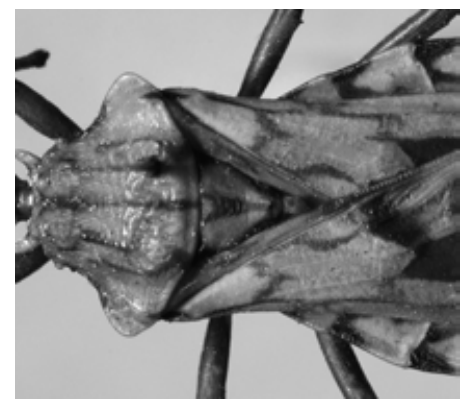

13 Escutelo amarelado com uma faixa mediana longitudinal preta; lobo anterior do pronoto sem tubérculos sublaterais; processo posterior do escutelo com forte corcova basal. P. humeralis
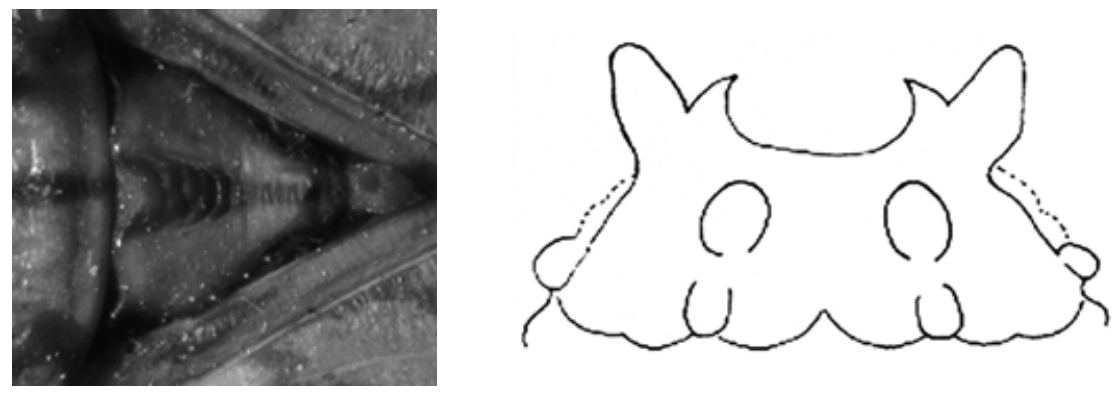
Escutelo com uma faixa mediana amarela; lobo anterior do pronoto com tubérculos sub-laterais além dos tubérculos discais e laterais; processo posterior do escutelo com leve corcova basal. P. lignarius
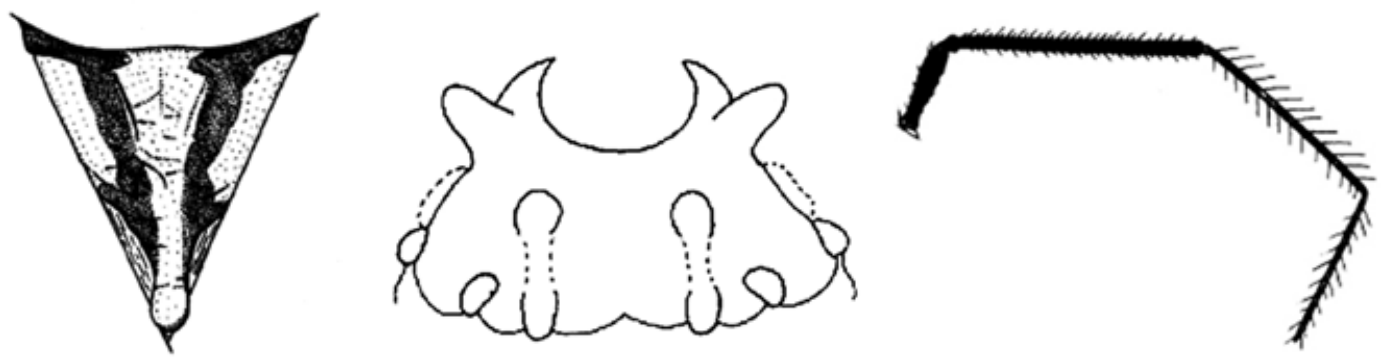

\section{Chave para as espécies do gênero Triatoma do Brasil}

1. Antenas com o primeiro artículo ultrapassando consideravelmente o ápice do clípeo, pronoto preto com os bordos laterais de cor avermelhada em toda a extensão; mancha clara do conexivo sobre as suturas inter-segmentares, em faixa estreita, adiante e atrás delas; abdômen nitidamente achatado mediana e longitudinalmente na face ventral.

T. rubrofasciata
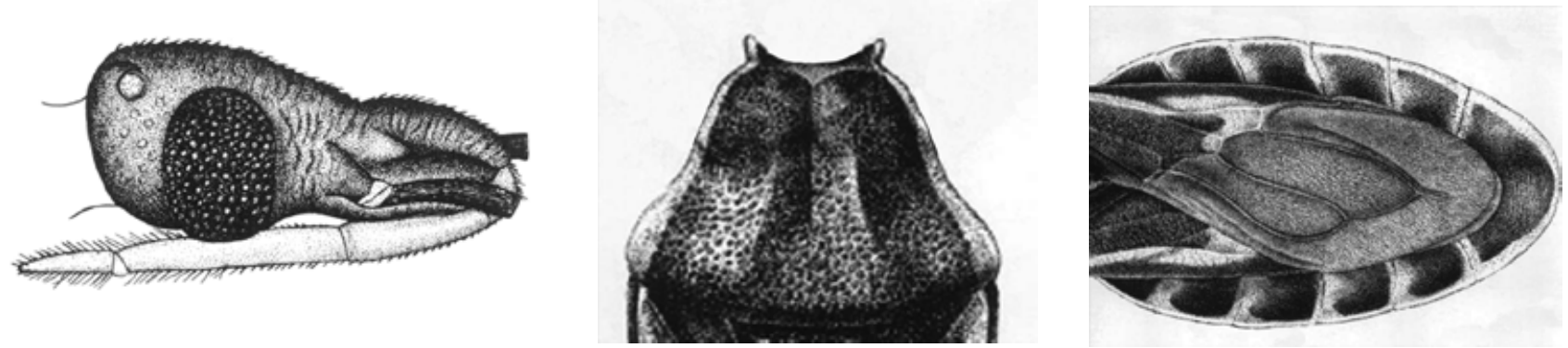

Antenas com o primeiro artículo não atingindo ou apenas atingindo o nível do ápice do clípeo; pronoto totalmente preto, castanho ou com manchas; mancha escura do conexivo anterior às suturas inter-segmentares, sobre, ou imediatamente atrás delas; abdômen convexo ventralmente.
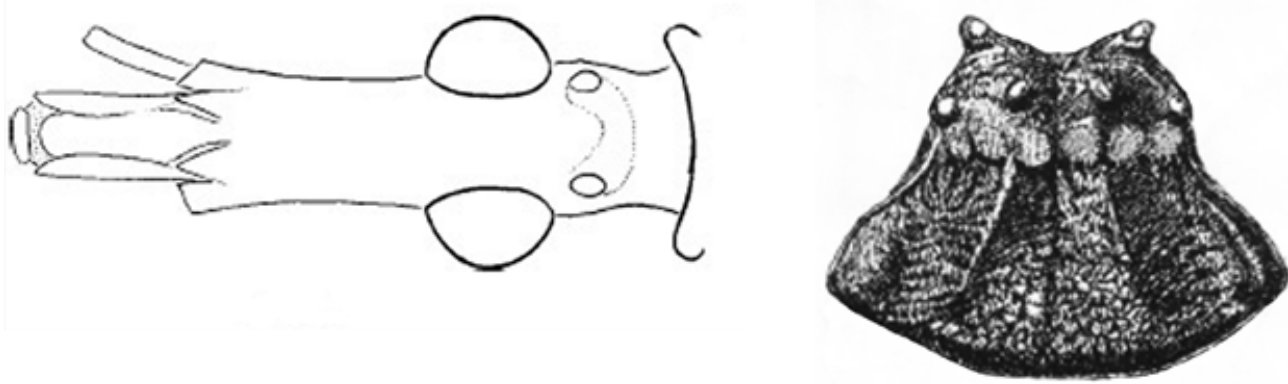
2. Tíbias castanhas; cabeça, pronoto, pleuras, prosterno e abdômen negros; cabeça maior que o pronoto; região anteocular 4,6 vezes maior que a pós-ocular; olhos em vista lateral não ultrapassando o limite superior da cabeça; conexivo ventral, sem máculas, conexivo dorsal também, quase sem máculas com exceção de uma pequena linha negra na sutura intersegmental.

T. vandae
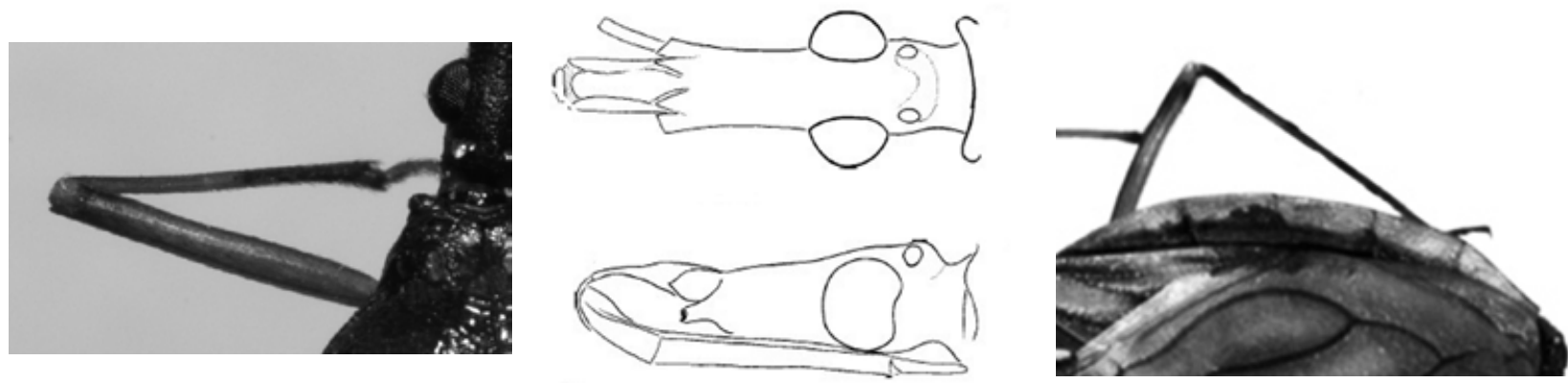

Tíbias de colorido uniforme ou com mancha no ápice ou com anelação clara sub-apical......... 3

3. Tíbias de colorido claro uniforme, exceto o ápice. .4

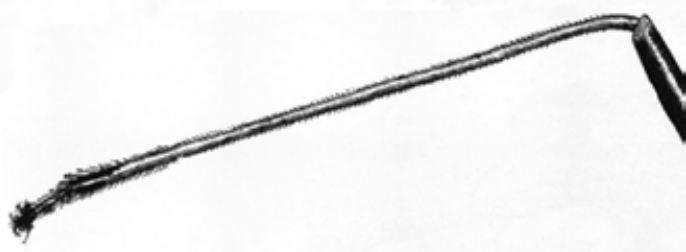

Tíbias de colorido mais escuro, uniforme, ou com anelação subapical
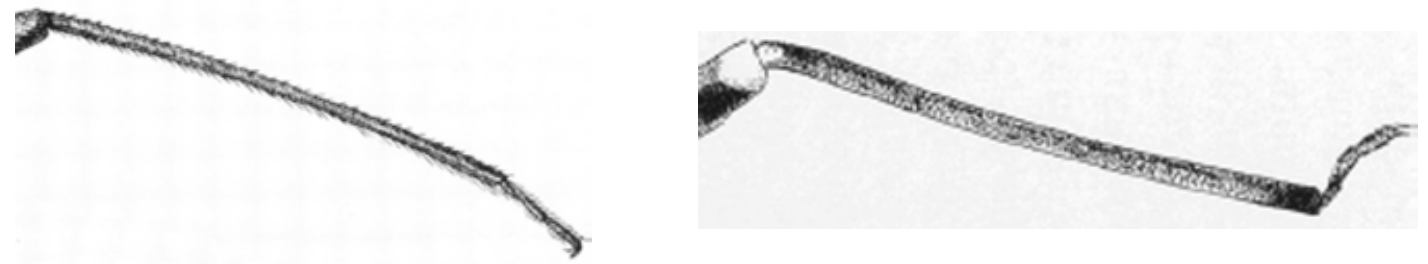

4. Fêmures predominantemente escuros, mancha escura do conexivo em faixa transversal larga imediatamente atrás das suturas inter-segmentares; pronoto escuro com os bordos laterais, o bordo posterior, os ângulos ântero-laterais e 1+1 faixas centrais sobre as carenas e os tubérculos discais, vermelho- alaranjados

T. tibiamaculata
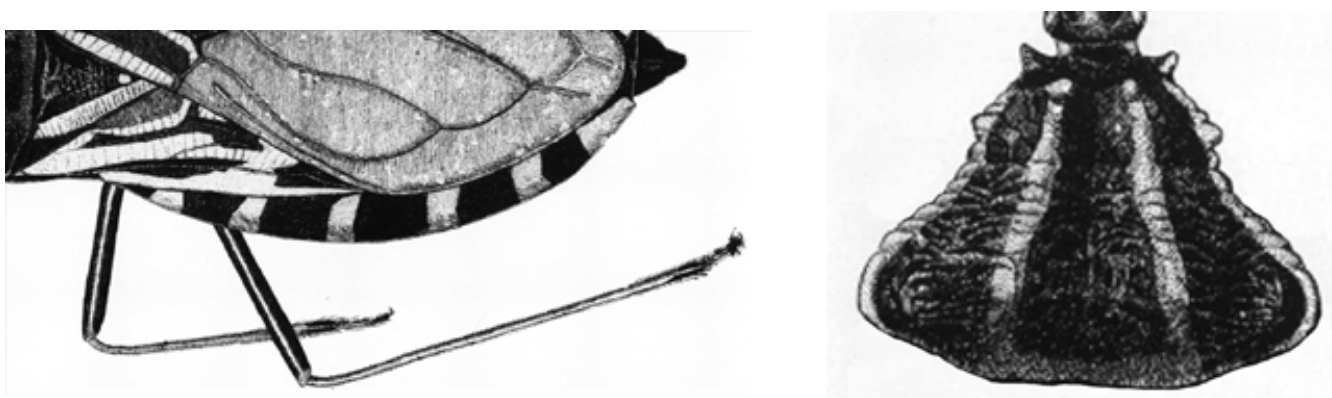
Fêmures predominantemente claros; conexivo com mancha escura estreita sobre as suturas inter-segmentares, daí ampliando-se para os bordos interno e externo; pronoto castanho com 1+1 manchas amareladas na região ad-humeral.

T. matogrossensis
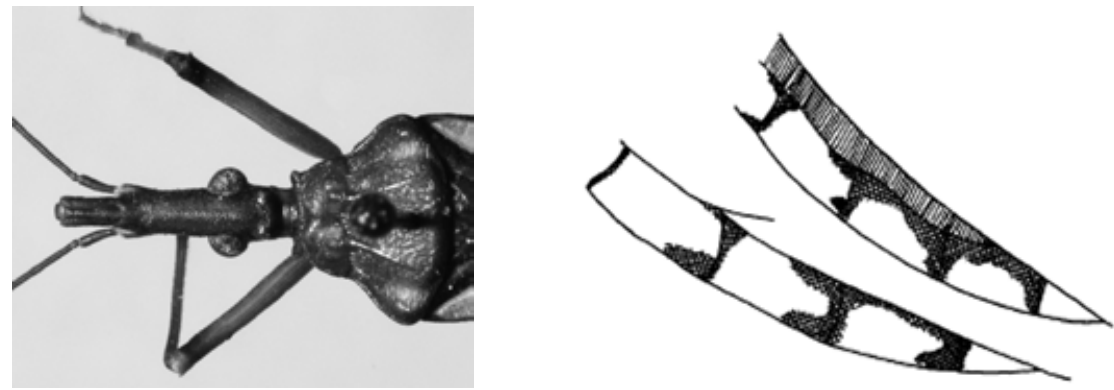

5. Fêmures com áreas claras e escuras; trocânteres claros ou não.
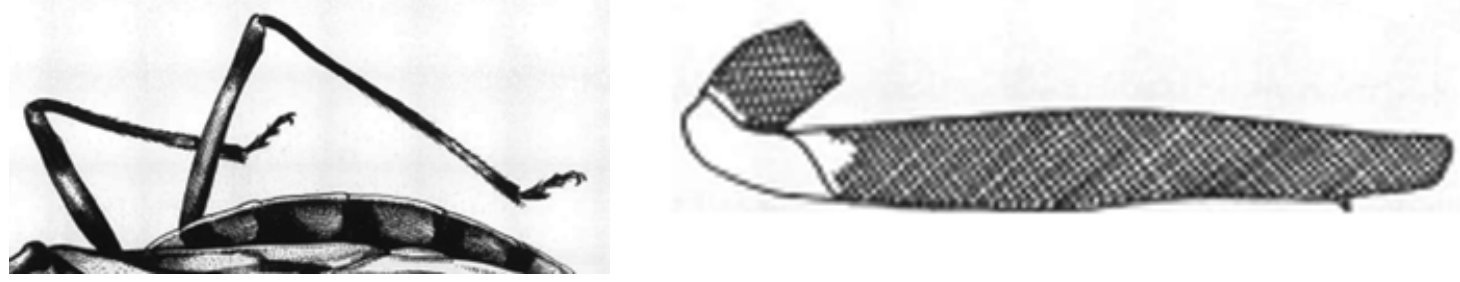

Fêmures inteiramente, trocânteres parcialmente ou inteiramente escuros.

6. Trocânteres escuros, fêmures escuros com anelação alaranjada na região mediana, hemélitros curtos, atingindo a bordo anterior do urotergito Vl; cabeça, pronoto e cório predominantemente negros T. sherlocki

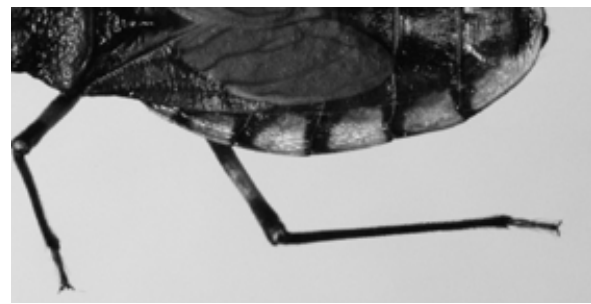

Trocânteres geralmente claros, amarelados, ou escuros com áreas claras; hemélitros de tamanho “normal"; manchas claras do tegumento amareladas.

7. Coxas claras, como a maior parte dos fêmures, fêmures com anel castanho subapical e manchas irregulares na superfície dorsal; pronoto castanho com 1+1 manchas amareladas nas regiões humerais

T. sordida
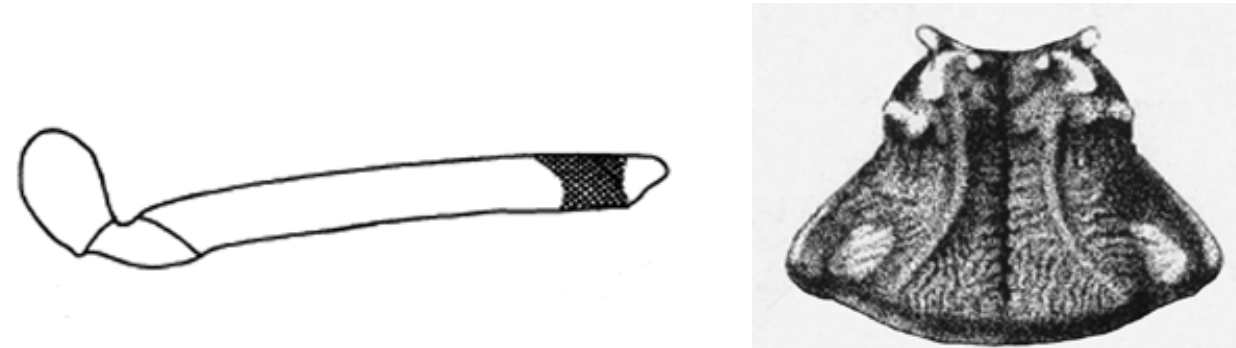
Coxas escuras, como a maior parte dos fêmures; fêmures e pronoto com outro aspecto 8

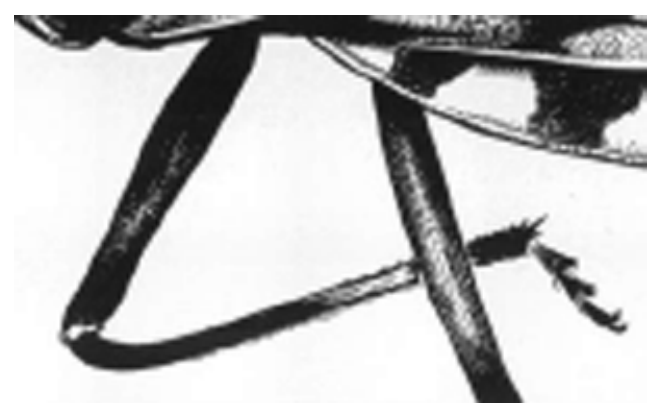

8. Pronoto escuro com 1+ 1 manchas amareladas.

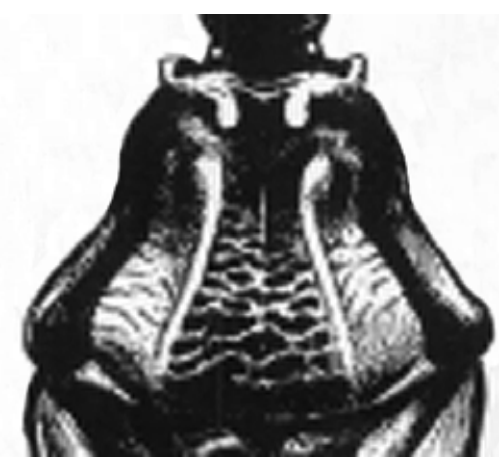

Pronoto totalmente negro ou com combinação de cores e manchas diferentes.

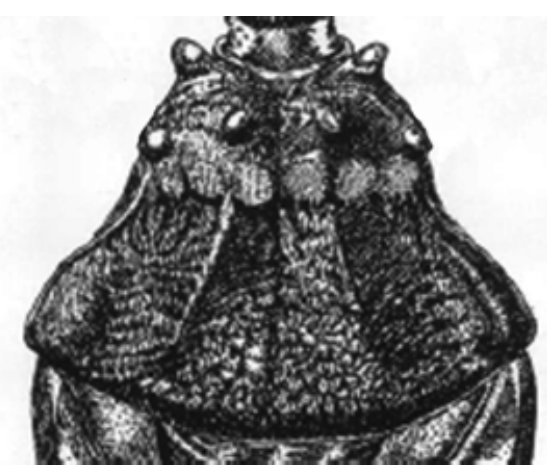

9. Trocânteres amarelos, fêmures com anelação clara na região sub-mediana, pronoto castanho com 1+1 manchas amarelas sobre as carenas longitudinais, desde seu início no lobo anterior até o bordo posterior; rostro grosso, segundo e terceiro artículos com pelos longos muito abundantes; manchas claras do conexivo amarelas. T. brasiliensis
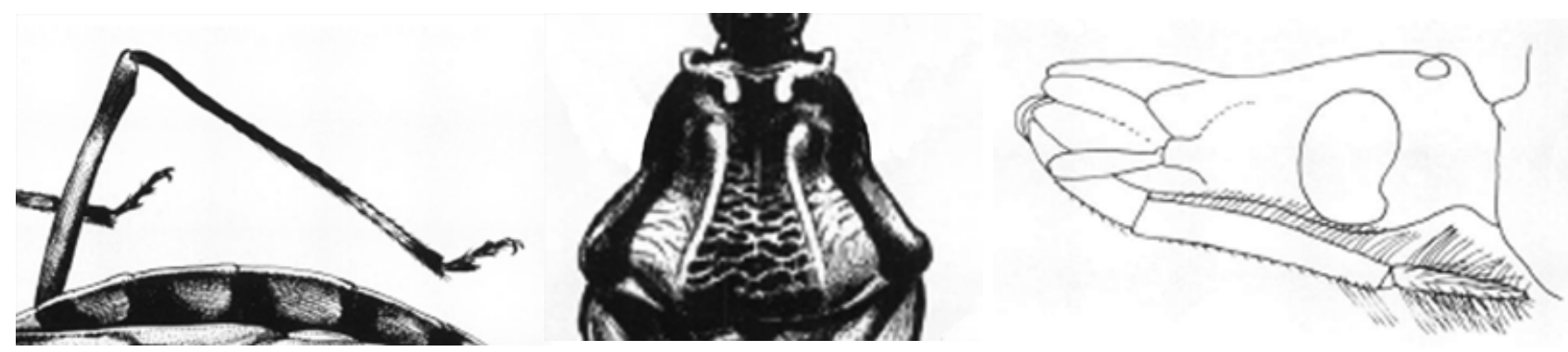
Pronoto com um par de nítidas manchas amarelas trapezoidais no lobo posterior não se estendendo ao lobo anterior; hemélitros com células discais inteiramente ou quase inteiramente castanho escuro; machos com fosseta esponjosa somente nas tíbias anteriores.

T. melanica
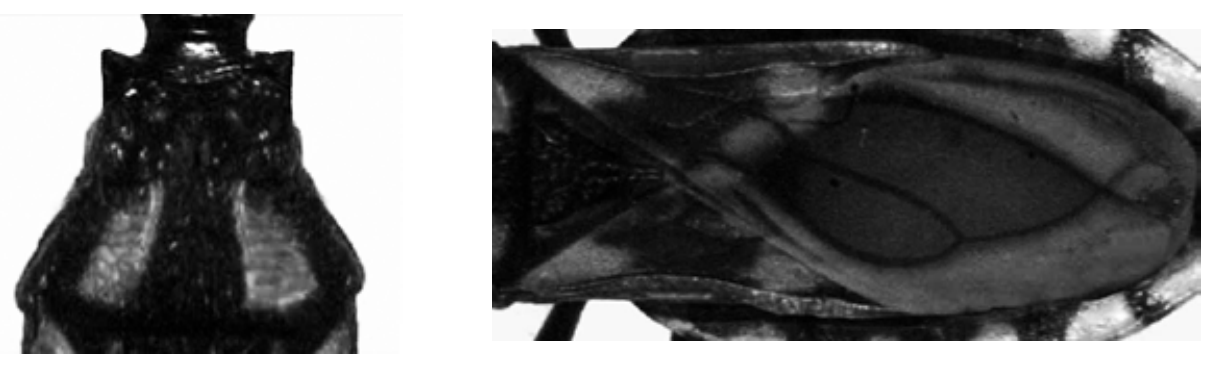

10. Fêmures totalmente negros; tíbias com porção subapical suavemente amarelada; pronoto totalmente negro T. juazeirensis

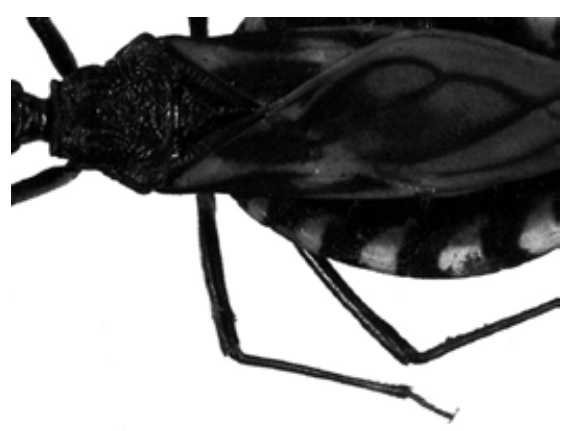

Diferente combinação de caracteres

11. Marcas escuras transversais do conexivo com a forma aproximada de notas musicais, cabeça mais longa que o pronoto

T. deaneorum
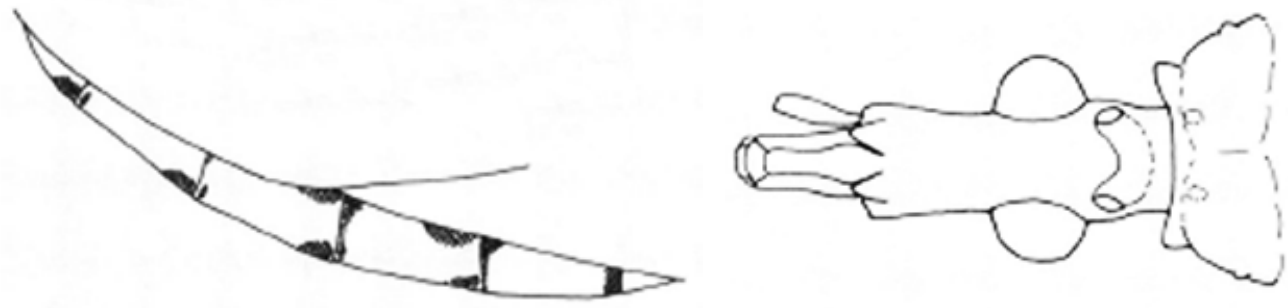

Marcas escuras transversais do conexivo em forma de faixas largas; cabeça tão longa quanto o pronoto T. infestans

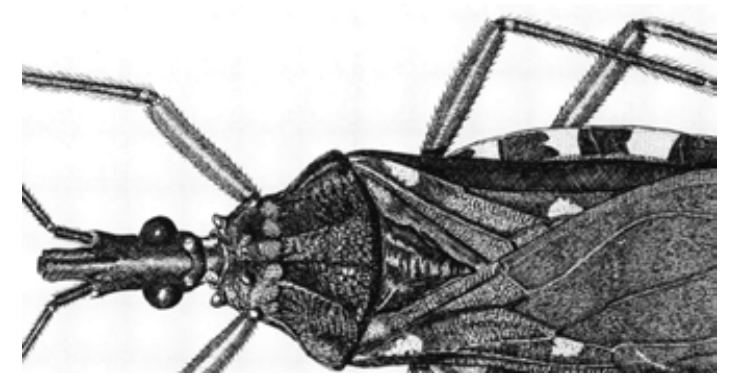


12. Cabeça de comprimento maior que o pronoto.

13

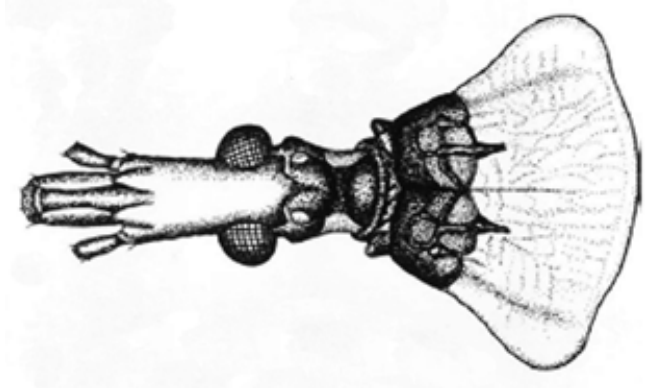

Cabeça de comprimento igual ou menor que o pronoto

.26

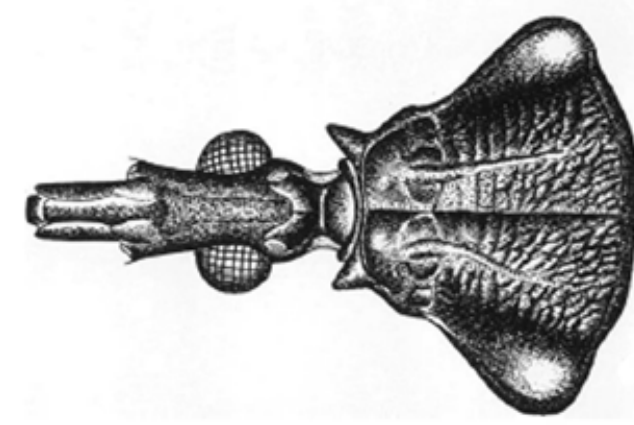

13. Espécies pequenas, com 15 a $17 \mathrm{~mm}$ de comprimento total; rostro com o terceiro segmento alongado, menor ou quase do mesmo comprimento do segundo. 14

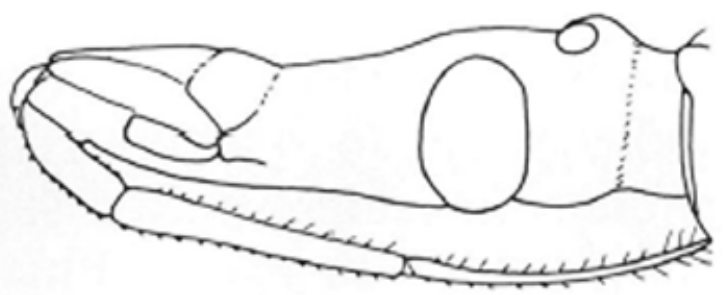

Espécies maiores; rostro com terceiro segmento distintamente mais curto do que o segundo.

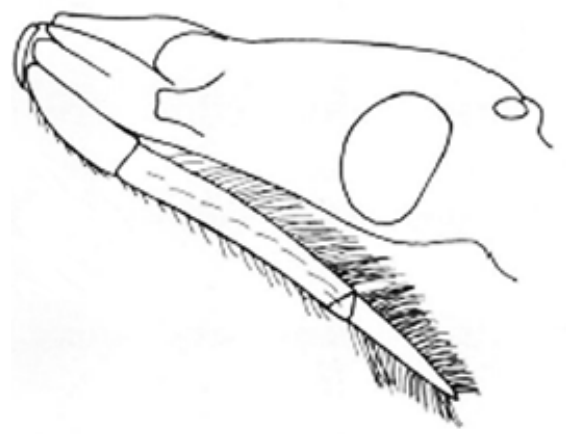


14. Razão do comprimento da cabeça/largura ao nível dos olhos 1:0,4-0,5; lobo posterior do pronoto de totalmente negro a totalmente vermelho, existindo padrões intermediários com manchas vermelhas de tamanho variável; largura do abdome 5,0-6,0 mm; genitália do macho com braços do suporte do falosoma unidos no ápice T. circummaculata

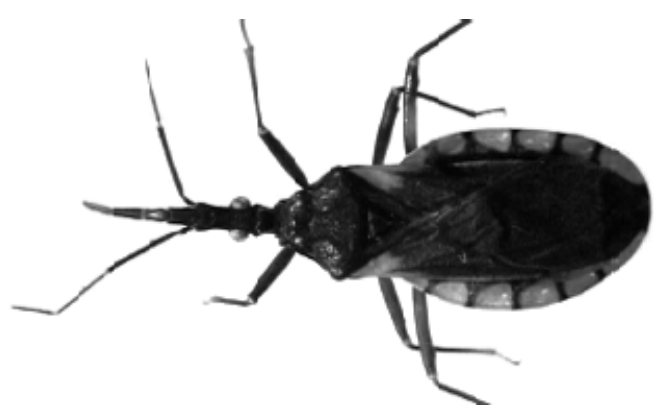

Razão do comprimento da cabeça/largura ao nível dos olhos 1:0,8; lobo posterior do pronoto inteiramente alaranjado ou amarelado; largura do abdome $6,85 \mathrm{~mm}$; genitália do macho com braços do suporte do falosoma separados no ápice

T. pintodiasi

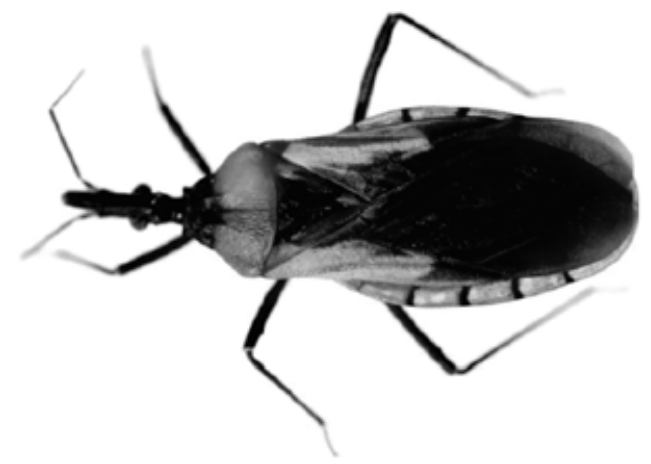

15. Antenas com o primeiro artículo afastado do nível do ápice do anteclípeo.

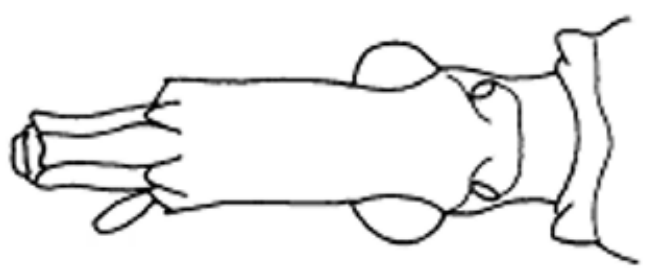

Antenas com o primeiro artículo quase atingindo, atingindo ou ultrapassando o nível do ápice do anteclípeo

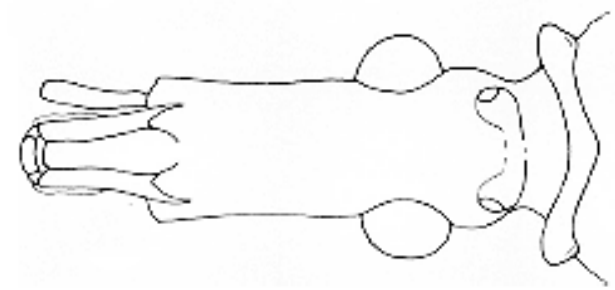


16. Pronoto escuro com áreas claras; manchas claras do conexivo em forma de largas faixas transversais ocupando toda a largura do segmento

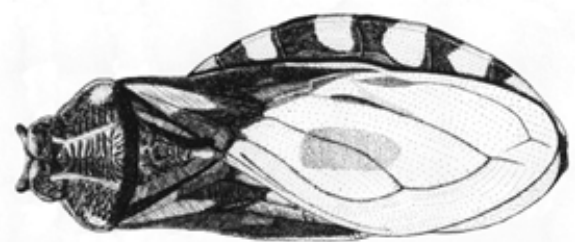

Pronoto quase sempre de cor uniformemente escura ou castanho-avermelhada (manchas claras podem estar presentes nos húmeros de T. jatai); manchas claras do conexivo diferentes.

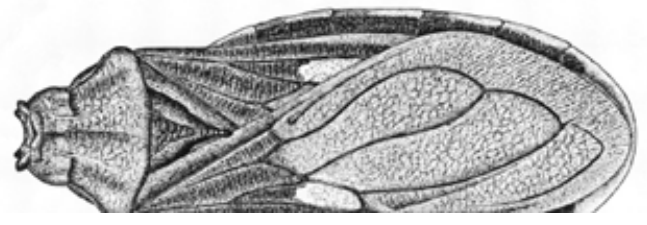

17. Tegumento preto com manchas alaranjadas e avermelhados no pronoto em quase todo o cório e parte da membrana; lobo posterior do pronoto fortemente alaranjado com exceção de uma longa linha mediana e $1+1$ pequenas linhas submedianas sobre parte das carenas; conexivo predominantemente alaranjado ou avermelhada com linhas negras nas duas margens de cada segmento, ventralmente a coloração avermelhada se estende até os urotergitos; lobos anteriores do pronoto com tubérculos discais bem desenvolvidos conectados por área elevada como uma ponte; húmeros elevados e arredondados; cabeça três vezes mais longa que larga; abdômen largo com parte dos urotergitos dorsais expostos.

T. carcavalloi
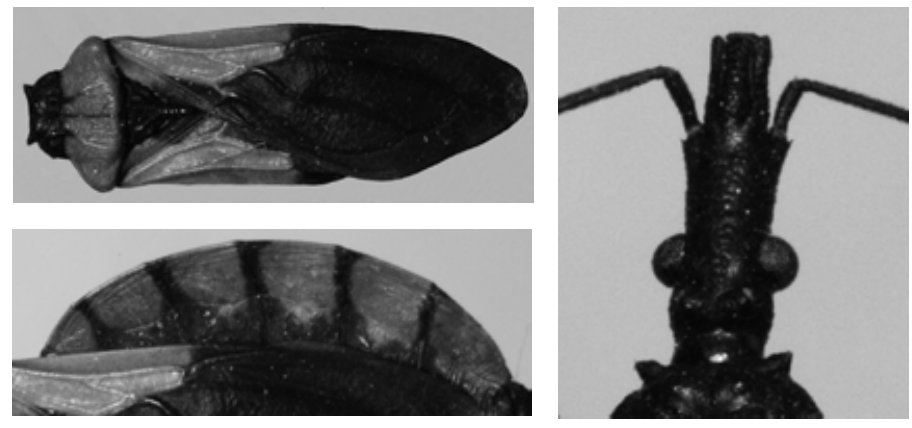

Tegumento castanho escuro com 1+1 marcações amareladas nos húmeros, nas porções basal e sub-apical do cório, em $2 / 3$ da área central de cada segmento do conexivo e em toda a extensão do processo apical do escutelo; membrana amarela com mancha escura sobre a nervura que separa as duas células discais; lobos anteriores do pronoto com tubérculos discais reduzidos a duas calosidades ovaladas transversais; húmeros pouco arredondados, quase angulares; comprimento da cabeça duas vezes a largura.

T. petrocchiae
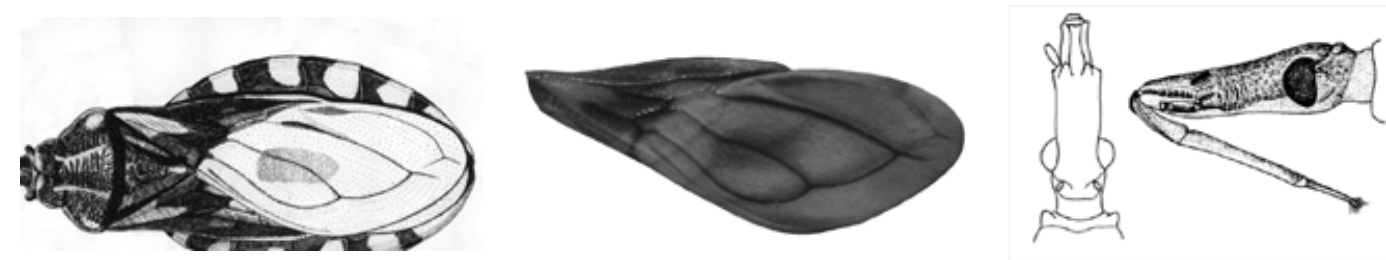
18. Cório dos hemélitros marrom ou preto com veias escuras e manchas mais claras n a metade apical; conexivo predominantemente escuro com manchas mais claras no contorno externo 19

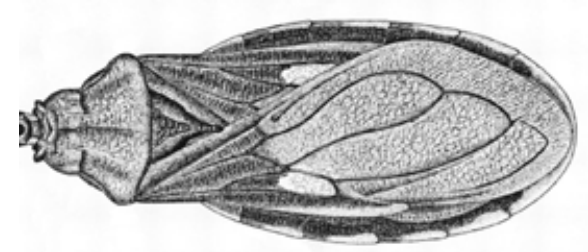

Cório dos hemélitros amarelado ou alaranjado com veias escuras; conexivo com coloração diferente

19. Coloração geral marrom com manchas amareladas; segundo e terceiro segmentos do rostro somente com cerdas curtas, mais numerosas no terceiro; hemélitro da fêmea atingindo no máximo a metade do sétimo urosternito; fosseta esponjosa presente somente nas tíbias anteriores do macho T. jatai

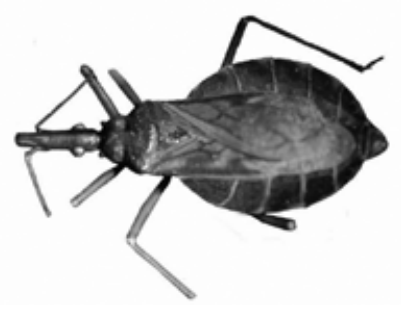

Coloração geral marrom escura a preta com manchas alaranjadas ou avermelhadas; segundo e terceiro segmentos do rostro com numerosas cerdas longas; hemélitro da fêmea atingindo o ápice do sétimo urosternito; fosseta esponjosa presente nas tíbias anteriores e medianas do macho

T. costalimai

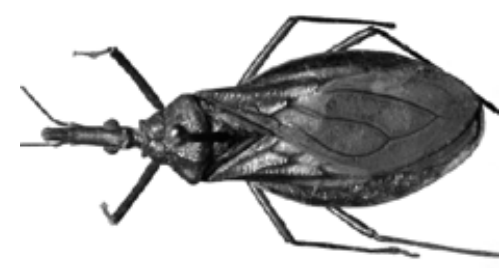

20. Pernas castanho avermelhadas, trocânteres amarelados, pequenos tubérculos em todos os fêmures; conexivo castanho escuro com mancha subtriangular alaranjada em cada segmento, que chega ventralmente até a sutura conexival; cabeça com região ante-ocular 6 ou mais vezes maior que a pós-ocular (1:0,16); hemélitros não alcançando o ápice do urotergito VII

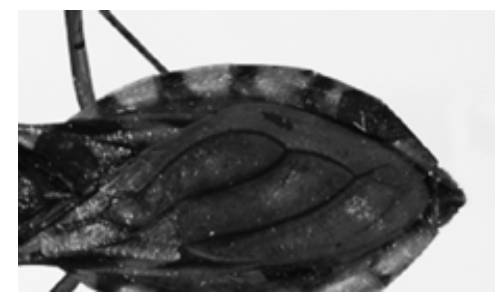

T. jurbergi

Pernas pretas, fêmures anteriores e medianos com pequenos tubérculos. 
21. Conexivo amarelo pálido com pequenas marcações escuras nas suturas inter-segmentares ao longo da borda externa e linha escura ao longo da sutura conexival; membrana marrom acinzentado, enfumaçado. Região anteocular quatro vezes maior que a pós-ocular. .T. williami
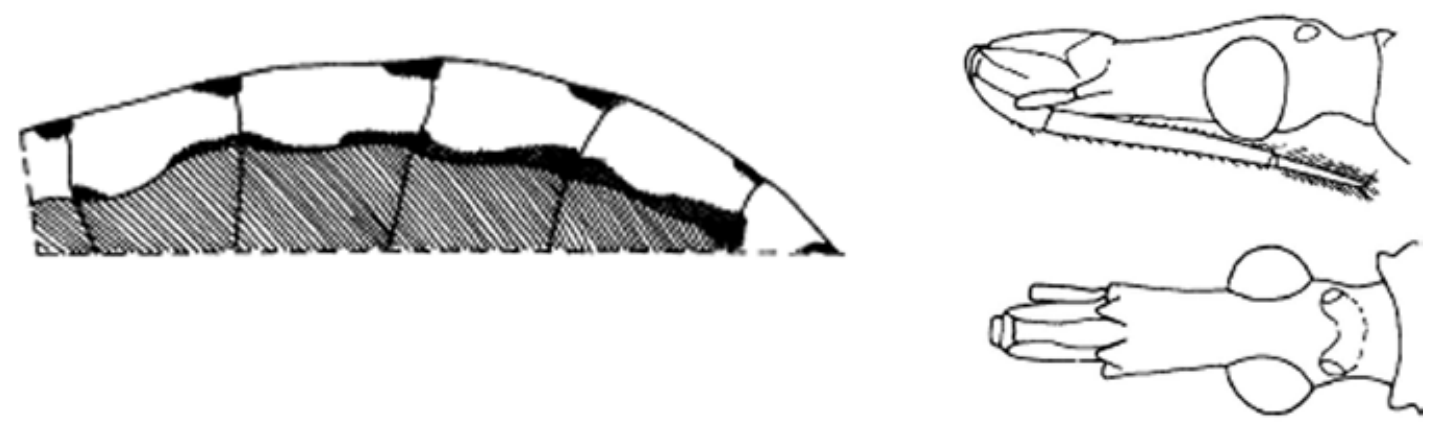

Conexivo amarelado ou alaranjado, a sutura escura visível só ventralmente; membrana enfumaçada; região anteocular cinco vezes maior que a pós-ocular.

T. baratai
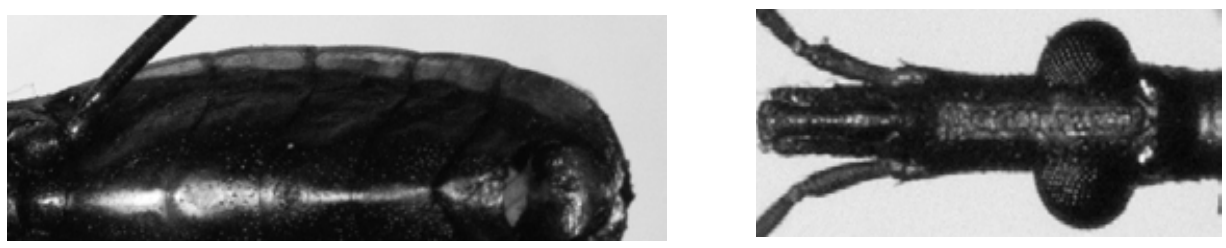

22. Processo apical do escutelo curto, menor que a metade do comprimento do corpo do escutelo......23

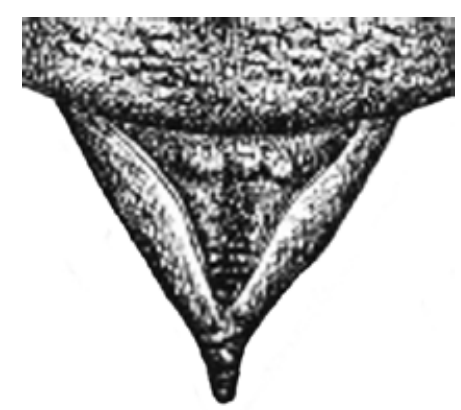

Processo apical do escutelo longo, maior que a metade do corpo do escutelo; cório dos hemélitros em geral totalmente preto, pronoto totalmente preto, manchas claras do conexivo amarelo-alaranjadas. ...T. lenti
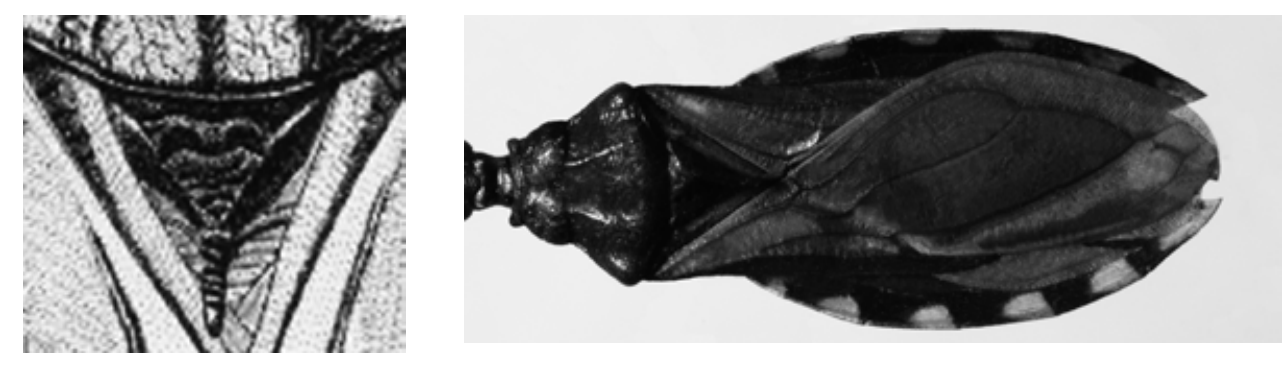
23. Hemiélitros atingindo o ápice do abdome dorsal; olhos grandes ultrapassando levemente o bordo inferior da cabeça em vista lateral.

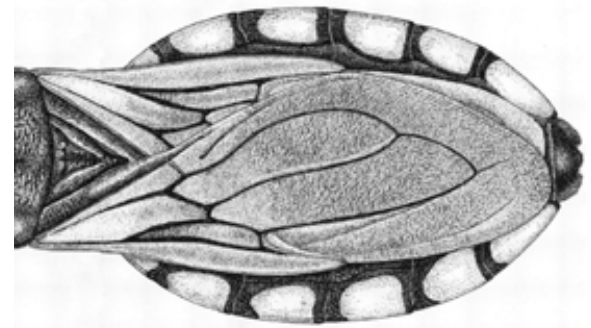

Hemiélitros curtos, deixando a mostra o urotergito VIl; olhos pequenos, não ultrapassando o bordo inferior da cabeça em vista lateral.

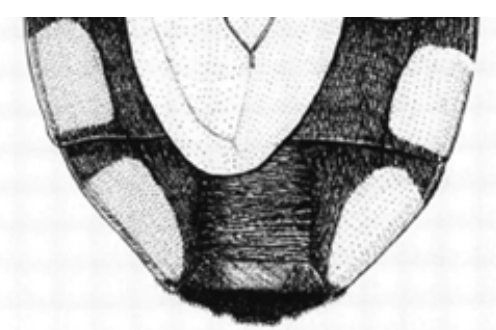

24. Cório com a metade basal amarelo claro, metade apical do cório e membrana marrom; cabeça com região anteocular quatro vezes maior que a pós ocular; olhos grandes ultrapassando levemente o bordo inferior da cabeça em vista lateral; processo apical do escutelo horizontal. T. guazu

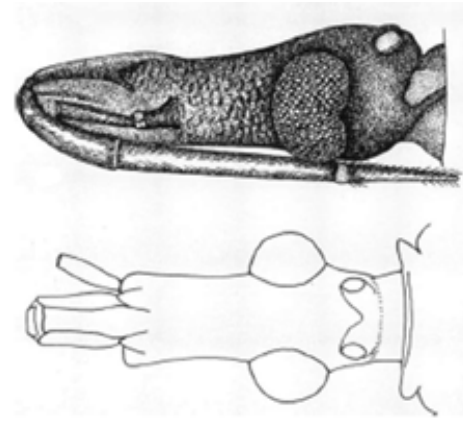

Cório dos hemélitros com manchas claras, pronoto totalmente preto ou manchado de vermelho com grande variabilidade cromática, manchas claras do conexivo vermelhas; rostro delgado, pouca pilosidade nos segundo e terceiro artículos; pronoto com o lobo anterior totalmente preto e o posterior manchado de vermelho em extensão variável a totalmente preto; manchas do conexivo vermelhas, cório dos hemiélitros com manchas vermelhas irregulares, às vezes de cor laranja ou amarela.

T. rubrovaria
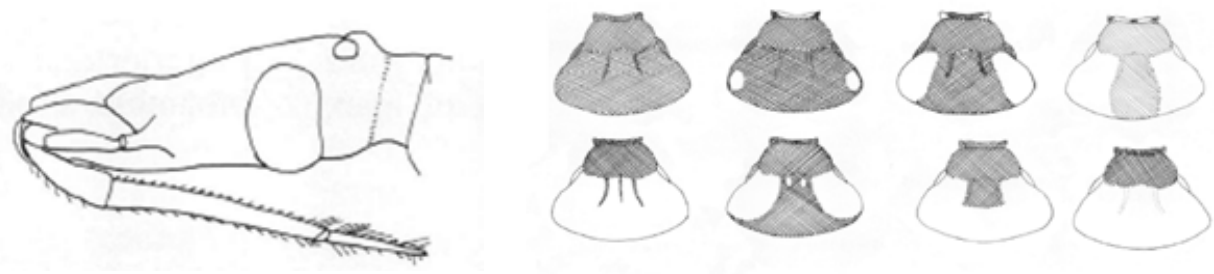
25. Hemiélitros não atingindo o ápice do urotergito VIl; cório amarelado com nervuras pretas e áreas mais escuras entre as nervuras, membrana castanho escuro com nervuras escuras; olhos, em vista lateral, atingindo o bordo inferior da cabeça; região anteocular 3,5 a 4 vezes maior que a pós-ocular T. klugi
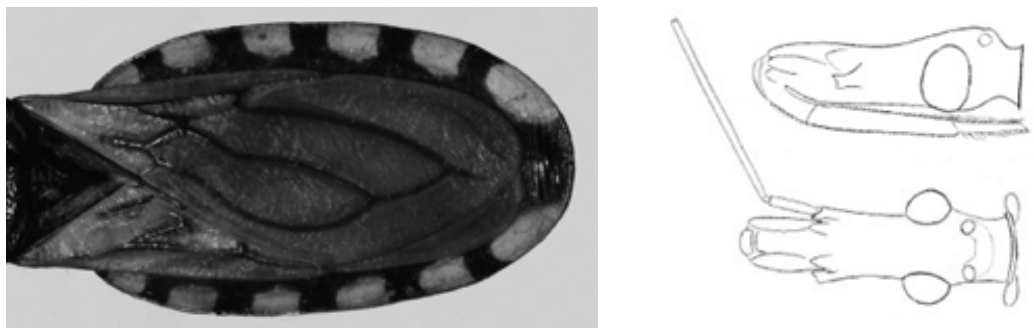

Hemiélitros curtos não atingindo ou ultrapassando levemente o limite entre os urotergitos VI e VII; cório e membrana amarelo pálido com nervuras escuras, mas sem marcas escuras entre as células; olhos não atingindo o bordo inferior da cabeça, em vista lateral; região anteocular três vezes maior que a pós-ocular.

T. oliveirai
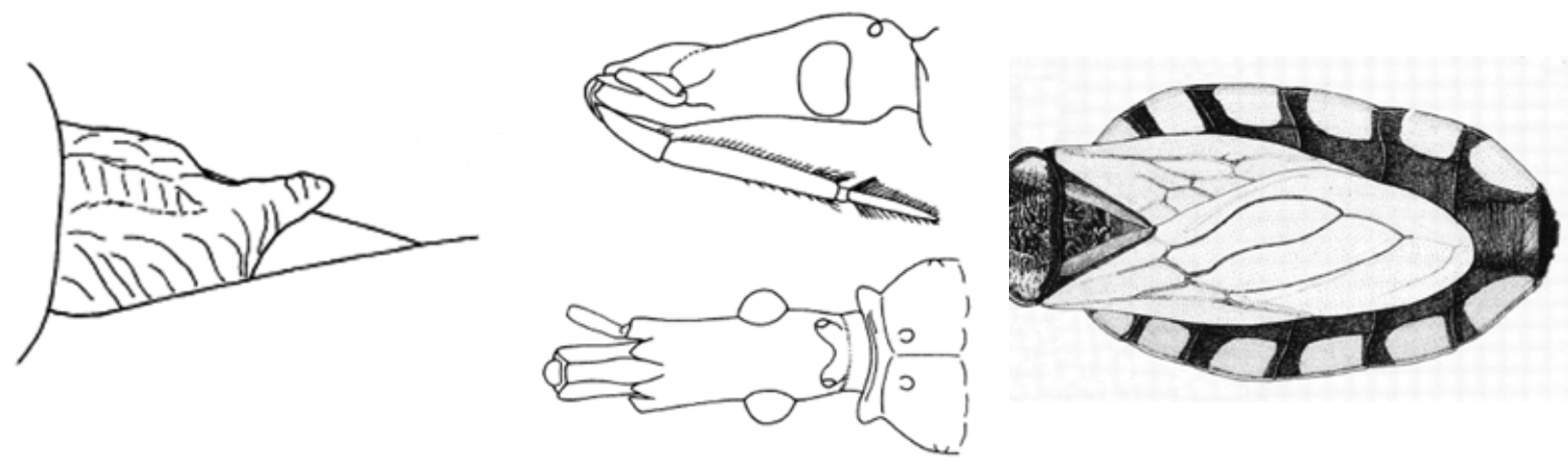

26. Genas não ultrapassando o ápice do clípeo ou apenas atingindo o seu nível; comprimento total $25 \mathrm{~mm}$ ou mais.

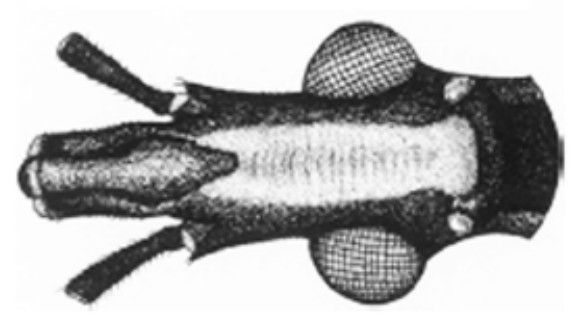

Genas ultrapassando nitidamente o nível do ápice do clípeo; comprimento 16,5-26 mm

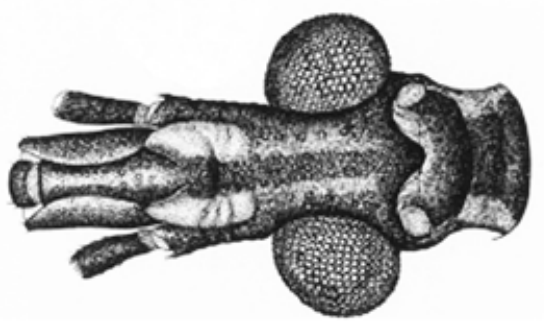


27. Preto com manchas vermelhas em faixa longitudinal dorsal na cabeça desde atrás do clípeo até o sulco interocular em 3+3 manchas no lobo posterior do pronto, sendo 1+1 entre as carenas e $2+2$ entre elas e os bordos laterias, como ainda na depressão central do escutelo; pleuras e face inferior do tórax e abdome fos$\cos$ T. vitticeps
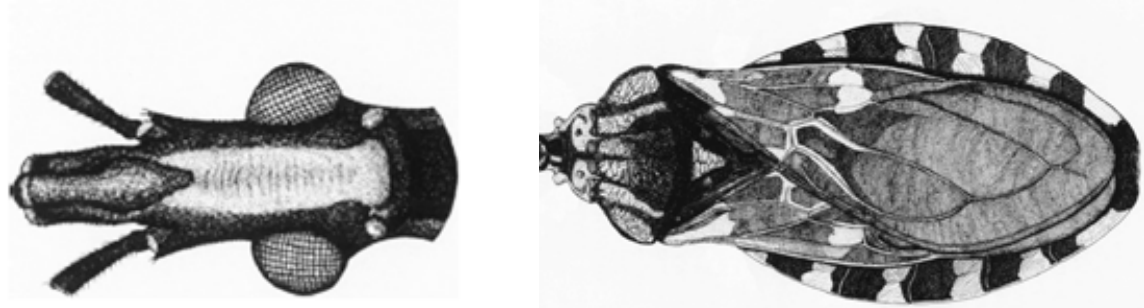

Preto com 1+1 manchas amarelas na metade anterior do lobo posterior do pronoto entre as carenas e os bordos laterais, mais próximo daquelas; preto na metade restante do pronoto e no escutelo; pleuras e face inferior do tórax e abdome muito polidas

T. melanocephala

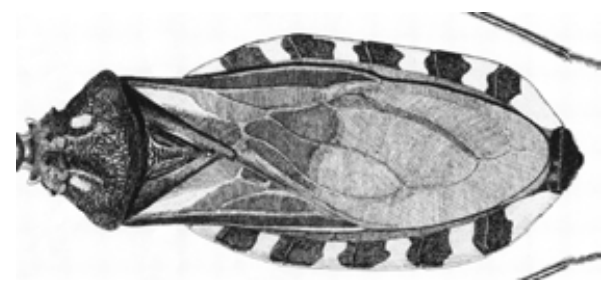

28. Pronoto com tubérculos discais e laterais no lobo anterior

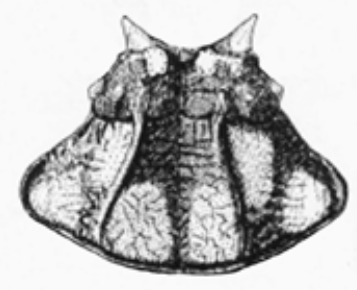

Pronoto sem tubérculos discais e laterais no lobo anterior

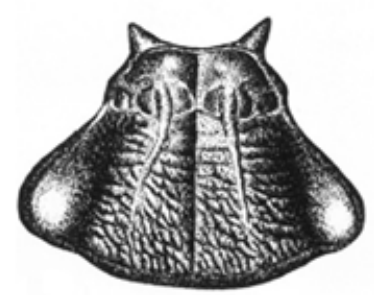

29. Clípeo fortemente alargado sub-basalmente; segundo e terceiro artículos do rostro com pelos longos abundantes.
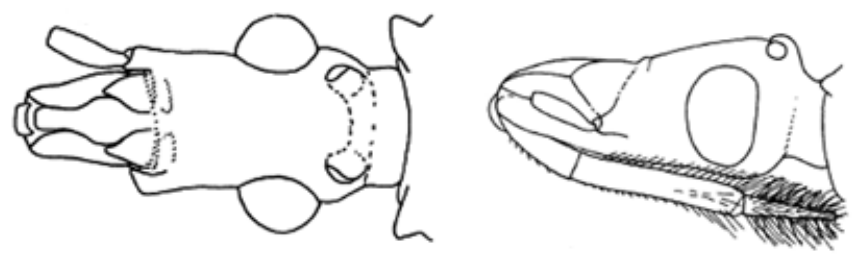
Clípeo muito pouco alargado sub-basalmente; segundo e terceiro artículos do rostro com pelos curtos ou somente o terceiro com pelos longos.
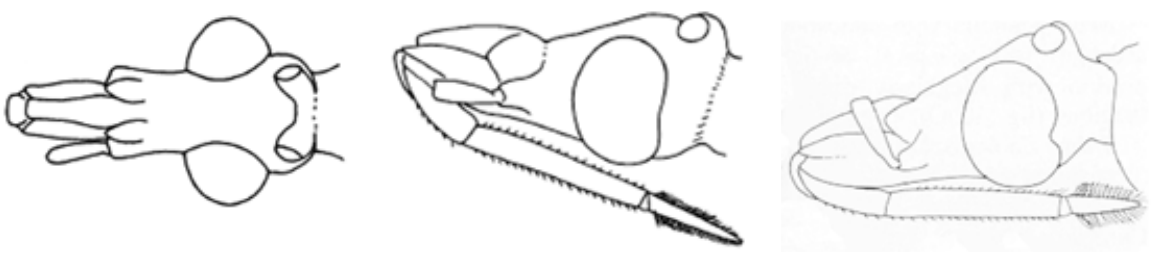

30. Pelos das tíbias posteriores mais curtos que o diâmetro do segmento, não perceptíveis sem aumento; corpo extremamente piloso; escutelo, na base, com 1+1 tubérculos salientes dirigidos para diante e atingindo o bordo posterior do pronoto

T. platensis
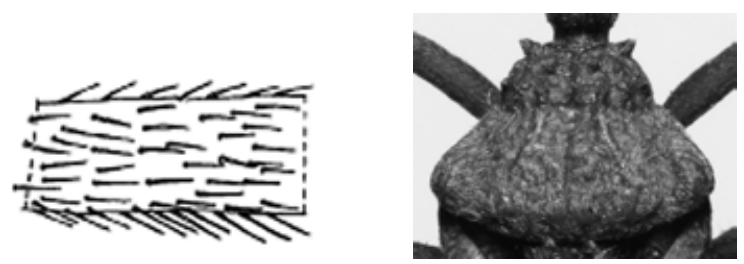

Pelos das tíbias posteriores mais longos, tanto quanto o diâmetro do segmento, facilmente visíveis sem aumento; corpo menos piloso, escutelo sem os tubérculos conspícuos mencionados T. delpontei
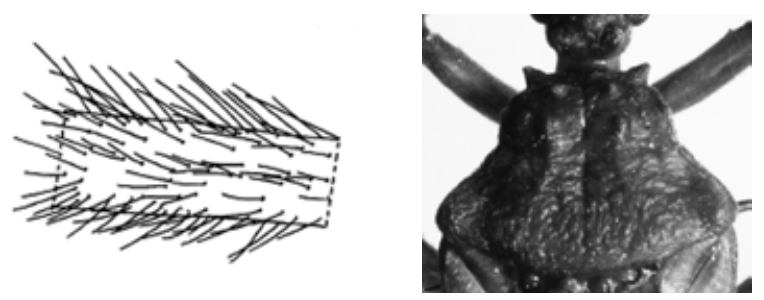

31 Cabeça com mancha vermelho-alaranjada dorsal mais ou menos extensa em forma de Y localizada sobre o clípeo, as genas, as jugas e prolongando-se, às vezes, entre os olhos, muito raramente toda preta; cabeça muito elevada atrás, na vista lateral; em muitos espécimes mancha clara na propleura e na mesopleura ou só na mesopleura; olhos grandes; rostro com primeiro artículo levemente maior que o terceiro, este com pelos muito longos; segundo artículo do rostro grosso de perfil; ângulos ântero-laterais mais apontados para a região anterior; processo do endosoma da genitália masculina sem dentículos no ápice.

T. maculata
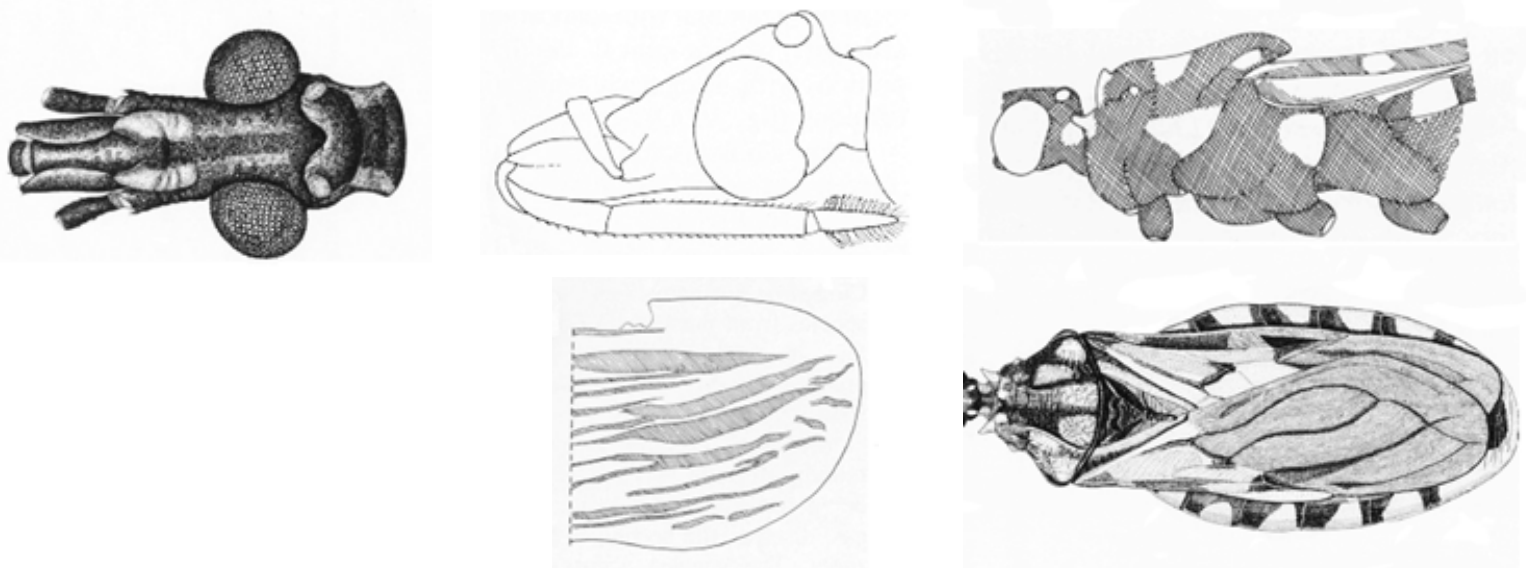
Cabeça de colorido preto uniforme dorsalmente, sem mancha vermelha dorsal e menos alta atrás, na vista lateral; manchas claras pleurais ausente ou só presentes na propleura; olhos menores; rostro com primeiro artículo levemente mais curto que o terceiro, aquele com pelos mais curtos; segundo artículo do rostro mais delgado de perfil; ângulos ântero-laterais mais direcionados para as laterais; processo do endosoma da genitália masculina com dentículos no ápice.

T. pseudomaculata
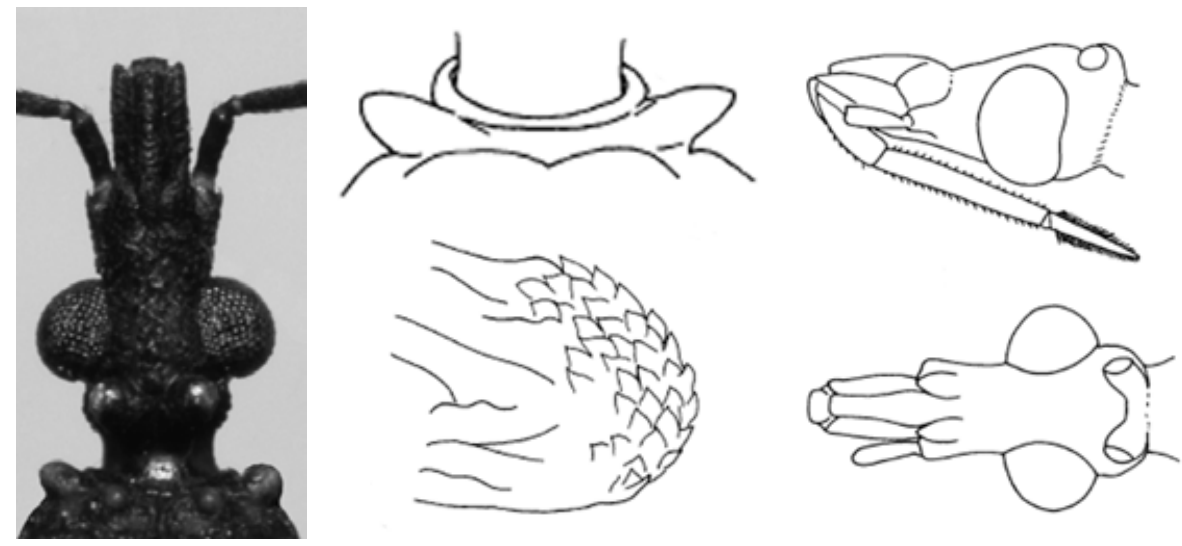

32. Pronoto de colorido escuro uniforme, cório dos hemiélitros quase totalmente escuro, com a metade apical do clavo e parte da célula corial adjacente a ela, enfumaçadas como a membrana; processo do endosoma da genitália masculina com muitos dentículos (cerca de 100)

T. arthurneivai
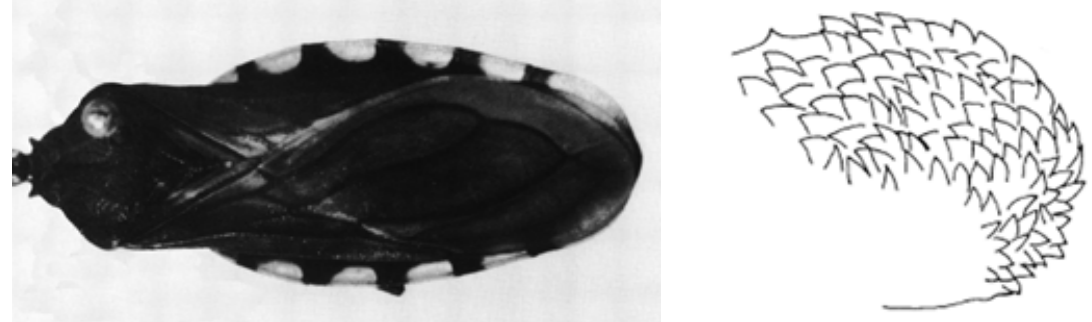

Pronoto escuro com 1+1 manchas avermelhadas nítidas nos ângulos humerais e, em alguns espécimes, com mancha avermelhada entre as carenas, perto do bordo posterior; cório dos hemélitros com manchas avermelhadas grandes e confluentes; processo do endosoma da genitália masculina com poucos dentículos (cerca de 20).

T. wygodzinskyi
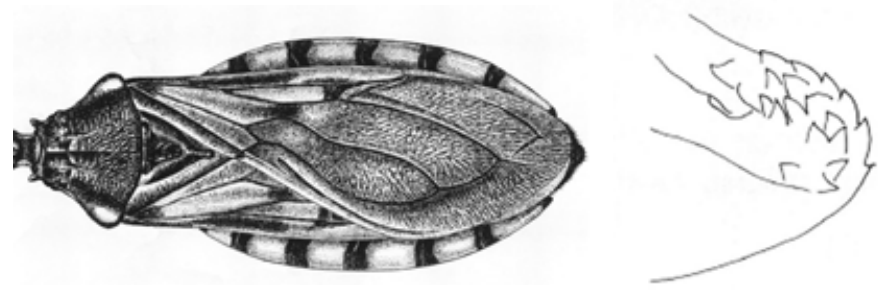